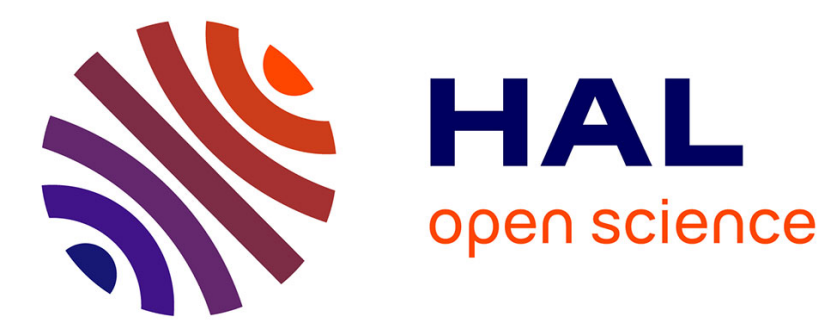

\title{
Surface-Active Mononuclear and Dinuclear Ru(II) Complexes based on Thio-substituted Terpyridines Bearing Cyclodextrin Recognition Units
}

\author{
Zoe Pikramenou, Patrick R Unwin
}

\section{- To cite this version:}

Zoe Pikramenou, Patrick R Unwin. Surface-Active Mononuclear and Dinuclear Ru(II) Complexes based on Thio-substituted Terpyridines Bearing Cyclodextrin Recognition Units. Supramolecular Chemistry, 2007, 19 (01-02), pp.115-127. 10.1080/10610270601026578 . hal-00513495

\author{
HAL Id: hal-00513495 \\ https://hal.science/hal-00513495
}

Submitted on 1 Sep 2010

HAL is a multi-disciplinary open access archive for the deposit and dissemination of scientific research documents, whether they are published or not. The documents may come from teaching and research institutions in France or abroad, or from public or private research centers.
L'archive ouverte pluridisciplinaire HAL, est destinée au dépôt et à la diffusion de documents scientifiques de niveau recherche, publiés ou non, émanant des établissements d'enseignement et de recherche français ou étrangers, des laboratoires publics ou privés. 


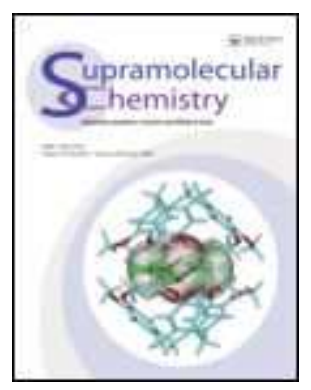

\section{Surface-Active Mononuclear and Dinuclear Ru(II) Complexes based on Thio-substituted Terpyridines Bearing Cyclodextrin Recognition Units}

\begin{tabular}{|r|l|}
\hline Journal: & Supramolecular Chemistry \\
\hline Manuscript ID: & GSCH-2006-0037.R1 \\
\hline Manuscript Type: & Special Issue Paper \\
\hline Date Submitted by the \\
Author: & 25-Aug-2006 \\
\hline Keywords: & $\begin{array}{l}\text { cyclodextrin, Ruthenium, surface, metal complexes, } \\
\text { electrochemistry }\end{array}$ \\
\hline
\end{tabular}

\section{ScholarONE" \\ Manuscript Central}




\title{
Supplementary Information \\ Surface-Active Mononuclear and Dinuclear Ru(II) Complexes based on Thio- substituted Terpyridines Bearing Cyclodextrin Recognition Units
}

\begin{abstract}
Maria José J. Pereira Silva, ${ }^{1}$ Paolo Bertoncello, ${ }^{2}$ Nikolaos N. Daskalakis, ${ }^{2}$ Neil Spencer, ${ }^{1}$ Benson M. Kariuki, ${ }^{1}$ Patrick R. Unwin ${ }^{2}$ and Z. Pikramenou ${ }^{1 *}$

${ }^{1}$ School of Chemistry, University of Birmingham, Edgbaston B15 2TT, UK.
\end{abstract}

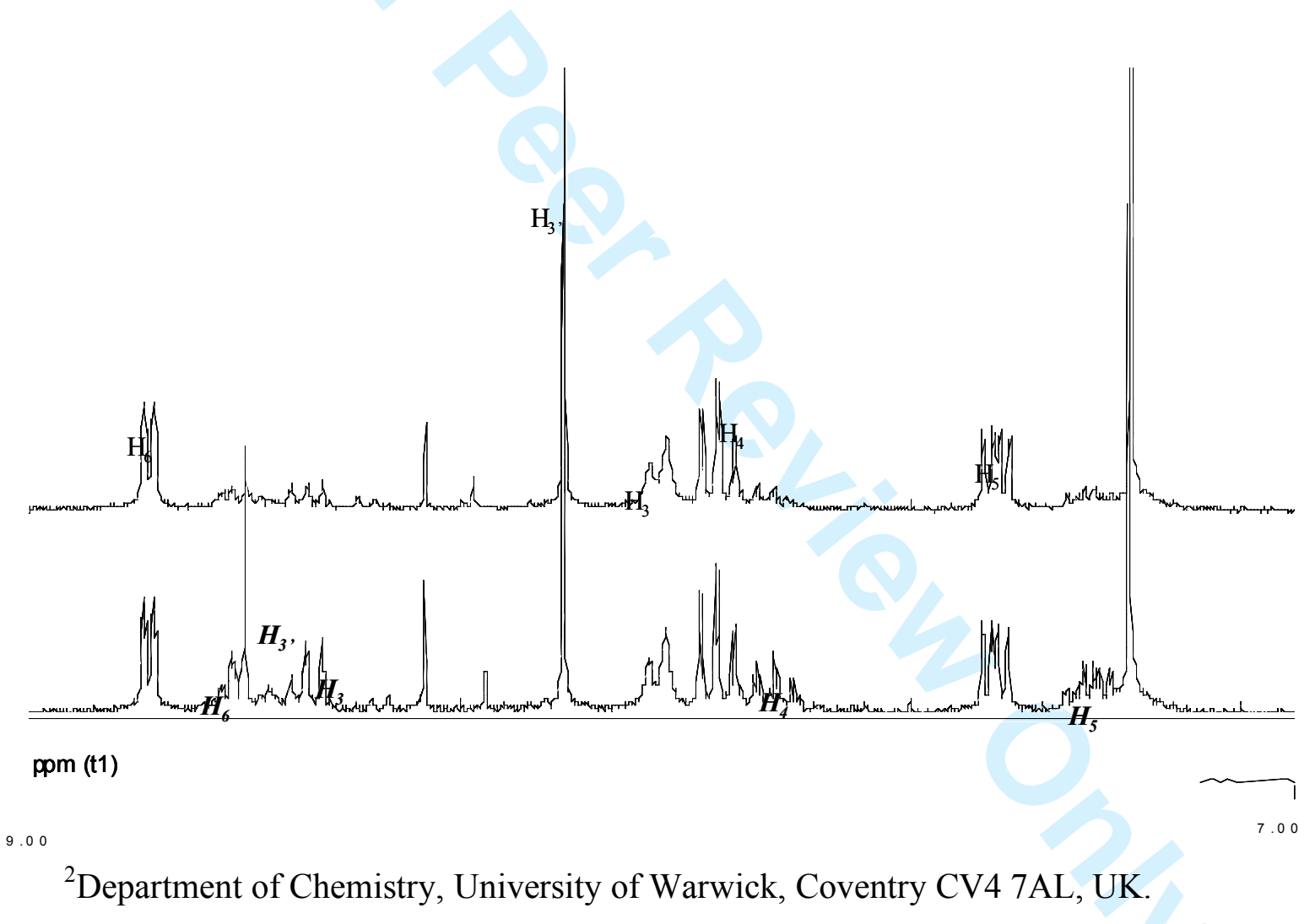

Figure S1. The $300 \mathrm{MHz}{ }^{1} \mathrm{H}$ NMR spectrum of tpySH in $\left(\mathrm{CD}_{3}\right)_{2} \mathrm{CO}$. 


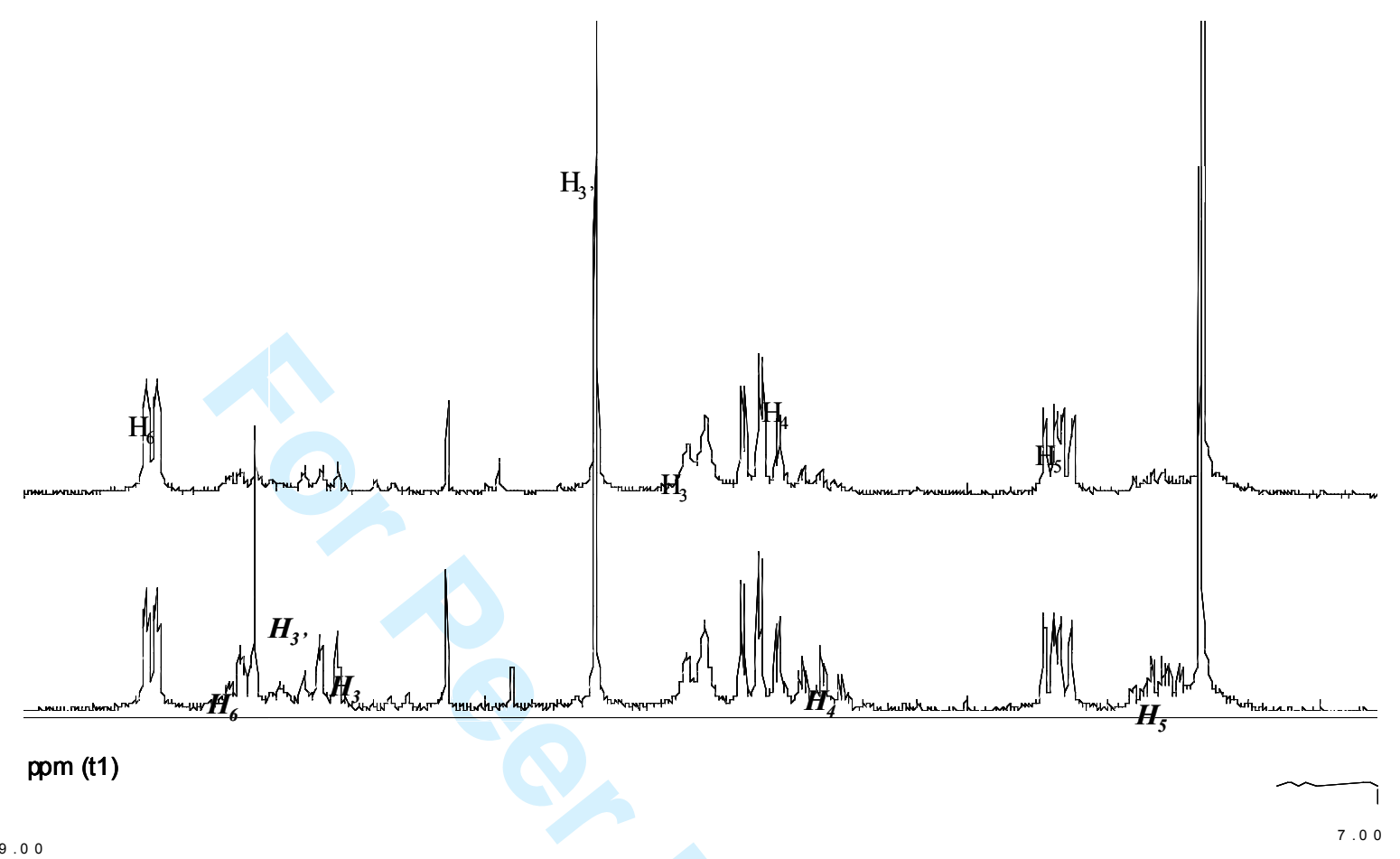

Figure S2. The $300 \mathrm{MHz}^{1} \mathrm{H}$ NMR spectra of tpySH in $\mathrm{CDCl}_{3}$; freshly made solution (top) and after 5 hours (bottom) with the minor by-product labelled in italic bold.

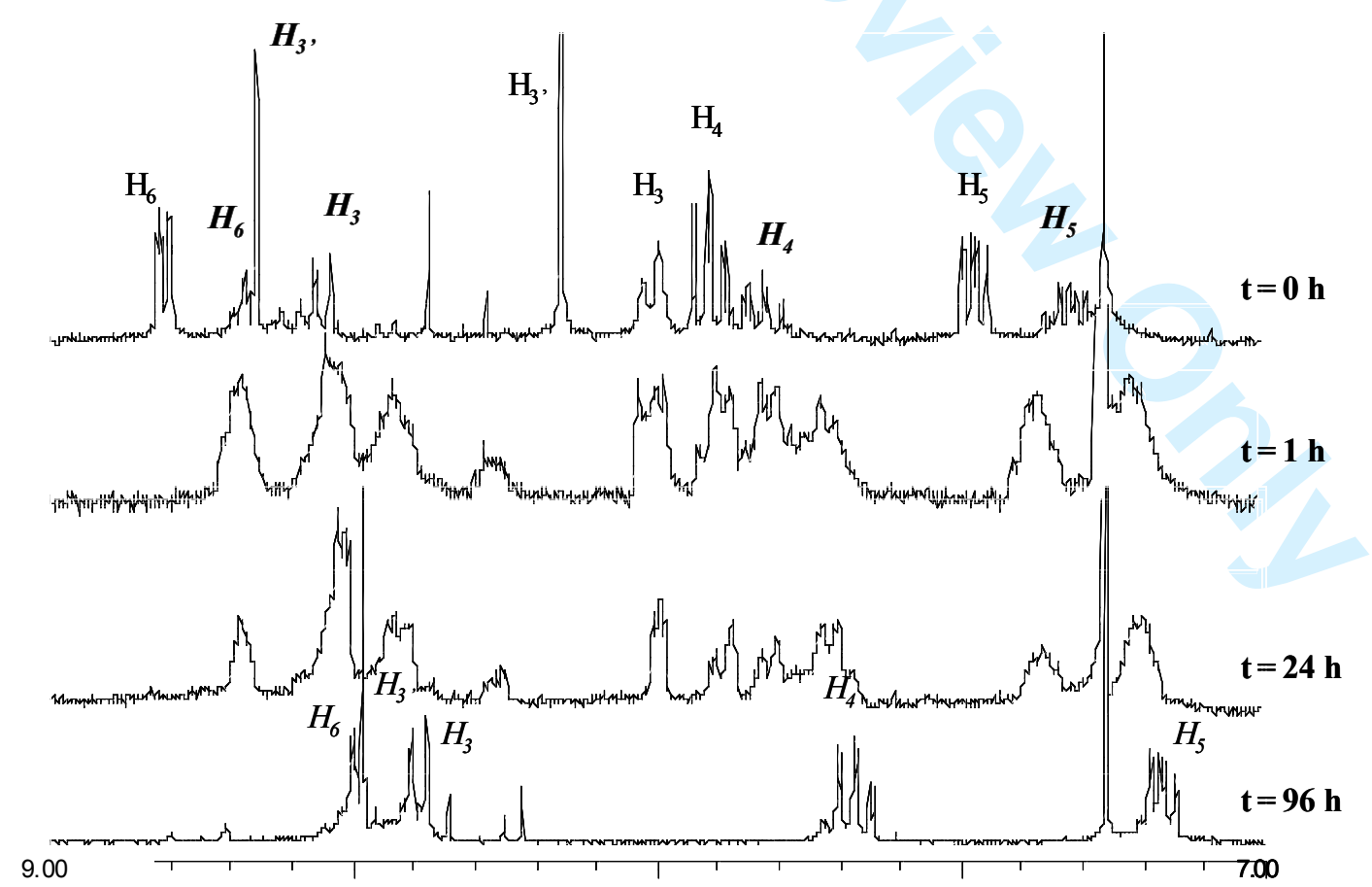

Figure S3. The $300 \mathrm{MHz}^{1} \mathrm{H}$ NMR spectra in $\mathrm{CDCl}_{3}$ at different times after addition of few drops of $d_{6}$-DMSO. Minor by-product labelled in bold and italic and tpySStpy in italic. 


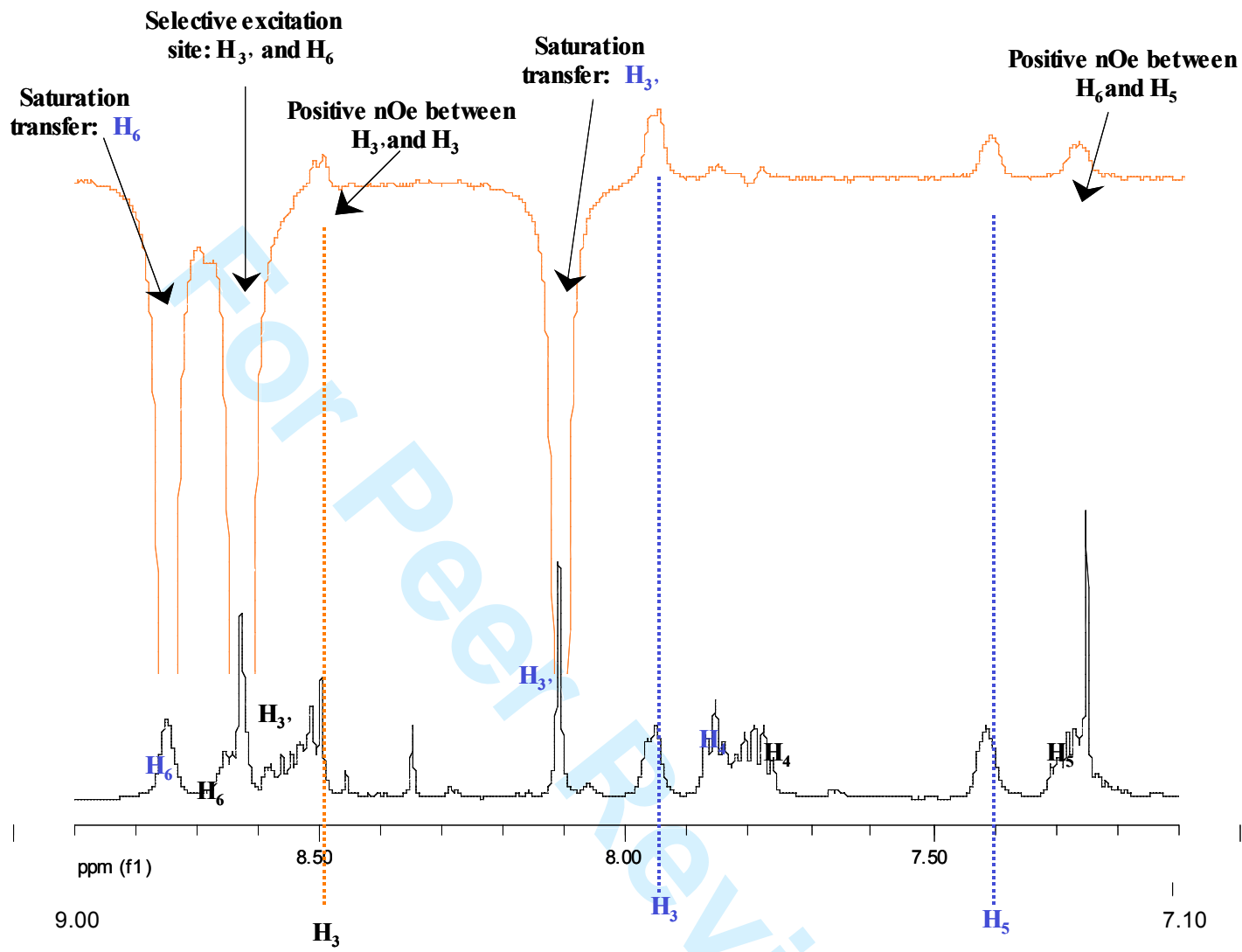

Figure S.4. The $500 \mathrm{MHz}$ 1D GOESY spectrum of tpySH in $\mathrm{CDCl}_{3}$ with selective excitation of $\mathrm{H}_{3}$, and $\mathrm{H}_{6}$ resonances at $8.62 \mathrm{ppm}$. 


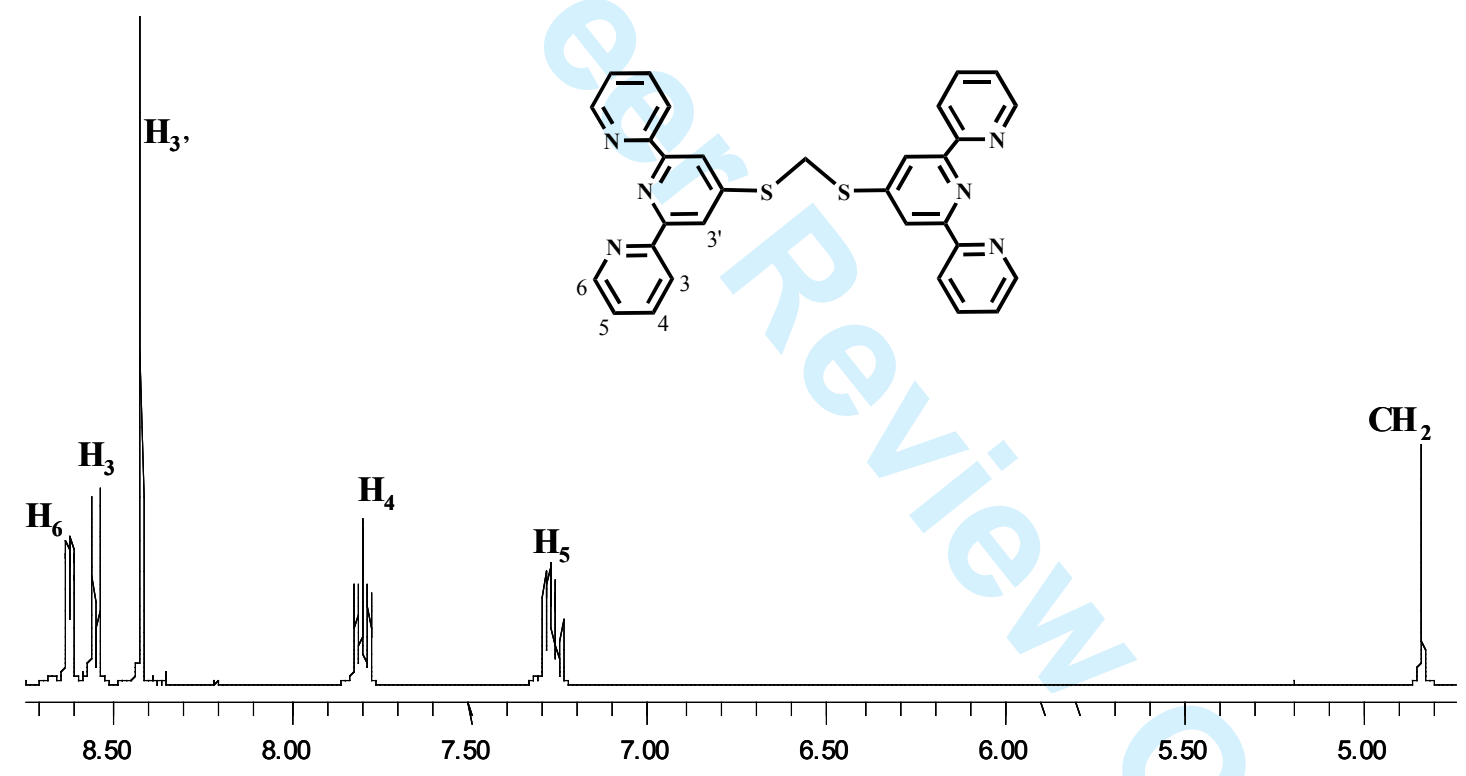

Figure S.5. The $400 \mathrm{MHz}^{1} \mathrm{H}$ NMR spectrum of tpySCH $\mathrm{Stpy}_{2}$ in $\mathrm{CDCl}_{3}$. 
Proofs to: $\quad$ Dr. Zoe Pikramenou

School of Chemistry

The University of Birmingham

Edgbaston B15 2TT

UK

tel: ++ 441214142290

fax: ++ 441214144446 or 4403

email: z.pikramenou@bham.ac.uk

\title{
Surface-Active Mononuclear and Dinuclear Ru(II) Complexes based on Thio- substituted Terpyridines Bearing Cyclodextrin Recognition Units
}

\author{
| Maria José J. Pereira Silva, ${ }_{-}^{1}$ Paolo Bertoncello, ${ }^{2}$ Nikolaos N. Daskalakis, ${ }^{2}$ Neil Spencer, ${ }^{1}$ Benson M. \\ Kariuki, ${ }^{1}$ Patrick R. Unwin ${ }^{2}$ and Z. Pikramenou ${ }^{1 *}$ \\ ${ }^{1}$ School of Chemistry, University of Birmingham, Edgbaston B15 2TT, UK. \\ ${ }^{2}$ Department of Chemistry, University of Warwick, Coventry CV4 7AL, UK.
}

\begin{abstract}
Ruthenium(II) surface active complexes based on a tpySH ligand have been prepared and characterised, (1) $[\mathrm{Ru}$ (tpyada) (tpySH) $]\left(\mathrm{PF}_{6}\right)_{2}$, (2) $[\mathrm{Ru}($ biptpy $)($ tpySH $)]\left(\mathrm{PF}_{6}\right)_{2}$ and (3) $[\mathrm{Ru}(\mathrm{pm}-\beta$ $\mathrm{CD}(\mathrm{ttp}))(\mathrm{tpySH})]\left(\mathrm{PF}_{6}\right)_{2}$. The complexes bear a surface active thiol group and a recognition unit which | is either a $\beta$-cyclodextrin or a hydrophobic tail (admantyl- or biphenyl) in order to utilise cyclodextrin recognition for the formation of supramolecular wires using bottom up approaches. Monolayers of | $\left[\mathrm{Ru}(\right.$ tpyada)(tpySH) $]\left(\mathrm{PF}_{6}\right)_{2}$ on ITO surfaces are studied by electrochemistry techniques. Detailed NMR analysis of tpySH reveals the presence of two tautomers, an "NH" and an "SH" form. The X-ray crystal structure of the oxidised form of the ligand tpySStpy is reported. A new ligand tpySCH $\mathrm{Stpy}_{2}$ is prepared and its dinuclear $\mathrm{Ru}(\mathrm{II})$ complexes are reported, (4) $\left[(\mathrm{ttp}) \mathrm{Ru}\left(\operatorname{tpyS} \mathrm{CH}_{2} \mathrm{Stpy}\right) \mathrm{Ru}(\mathrm{ttp})\right]^{+2}$, (5)

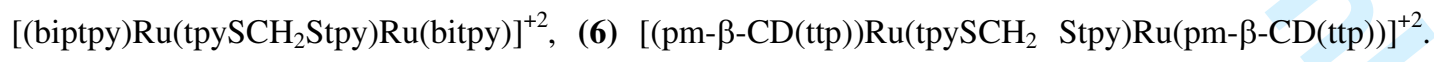
The complexes show characteristic red ${ }^{3}$ MLCT luminescence which is much stronger than their analogous mononuclear counterparts.
\end{abstract}




\section{Introduction}

Attachment of polypyridyl metal complexes on surfaces is attractive for the formation of molecular wires based on the photochemical and electrochemical properties of the metal centres. Ruthenium(II) and osmium(II) tris(bipyridyl) complexes have been modified with thiol groups and their monolayers have been studied by surface, electrochemical techniques ${ }^{1,2,3,4,5}$ and more recently by luminescence spectroscopy. ${ }^{5}$ Moreover, a device based on nanostructured $\mathrm{TiO}_{2}$ films with a functionalised $\mathrm{Ru}$ (II) tris(bipyridyl) complex covalently attached to a viologen unit has been used to demonstrate a write, read and erase process when incorporated in a sealed two-electrode cell. ${ }^{6}$

To design linear arrays of metal complexes, terpyridine ligands provide the advantage of directionality control for building complexes from the surface. ${ }^{7}$ The formation of self-assembled monolayers of $\mathrm{Co}, \mathrm{Cr}$ and $\mathrm{Os}$ complexes on $\mathrm{Au}$ electrodes and their electrochemical characterization has been reported. ${ }^{8} \mathrm{Co}(\mathrm{II})$ thiol terpyridine complexes have also been considered as suitable single| molecule transistors. ${ }^{9,10}$ The use of a pyridine surface anchoring group on terpyridines has led to formation of mono and dinuclear $\mathrm{Ru}(\mathrm{II})$ and $\mathrm{Os}(\mathrm{II})$ complexes. $^{11}$

We have been interested in the design of supramolecular wires based on metalloguests and metallocomplexes. ${ }^{12-15}$ Metallocyclodextrins provide functional building blocks for supramolecular systems with a photoinduced function. ${ }^{16-19}$ We have recently demonstrated that unidirectional energy transfer can take place in a solution assembled $\mathrm{Ru}(\mathrm{II})$ cyclodextrin junction. ${ }^{20,}{ }^{21}$ In order to develop capability of forming supramolecular wires on surfaces, we have prepared thiol-active metalloguests and metallocomplexes. We also developed a new bis-terpyridine ligand that led to formation of interesting dinuclear ruthenium complexes.

\section{Results and Discussion Synthesis and characterisation of thio-substituted 2,2':6',2''-terpyridines}

We have chosen to synthesize a tpySH ligand due to its versatility and one step synthesis (Scheme 1). The tpySH compound was synthesised using a modified method from the published procedure. ${ }^{9,22} \mathrm{We}$ found that the reaction was very sensitive to temperature, the quantity and quality (freshness) of $\mathrm{NaSCH}_{2} \mathrm{CH}_{3}$ leading to formation of tpySCH $\mathrm{S}_{2} \mathrm{Stpy}$ (Scheme 2) which we now have independently synthesized and characterized. We have introduced an additional modification at the final step by treating the compound with hydrazine ${ }^{23}$ since we found formation of the oxidized product tpySStpy (Scheme 2). 
Scheme 1.<smiles>Clc1cc(-c2ccccn2)nc(-c2ccccn2)c1</smiles>

Scheme 2.

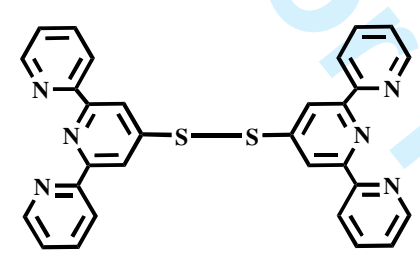

tpySStpy

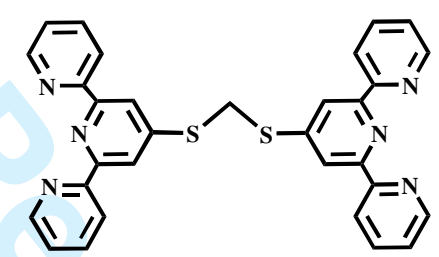

tpySCH$_{2} \mathrm{Stpy}$

The ${ }^{1} \mathrm{H}$ NMR of tpySH was recorded in $d_{6}$-acetone and the characteristic resonances of a 4' substituted terpyridine were present between 8.7-7.2 ppm (Supplementary Info). However, when the ${ }^{1} \mathrm{H}$ NMR of this compound was recorded in $\mathrm{CDCl}_{3}$ a small set of peaks indicated the presence of a minor byproduct. The peaks of the minor by-product increased in intensity with time (Supplementary Info). To examine the nature of the by-product a few drops of $d_{6}$-DMSO were added to a fresh solution of the compound in $\mathrm{CDCl}_{3}$ and the NMR spectrum was recorded through the course of several days. It is well known that DMSO can act as an oxidising agent for thiol groups producing the disulfide derivative. ${ }^{24,25}$ After leaving the solution standing for 4 days, the ${ }^{1} \mathrm{H}$ NMR presented only one set of terpyridine resonances at a new set of chemical shifts, which showed a peak in ES-MS corresponding to the disulfide derivative, tpySStpy.

In order to elucidate the identity of the minor by-product present in a $\mathrm{CDCl}_{3}$ solution, $1 \mathrm{D}$ GOESY studies were performed. In this experiment specific resonances of each one of the sets of terpyridine resonances were selectively excited and the nOe signals observed from the 1D GOESY experiment were examined. This was aimed at elucidating the possibility of the existence of two tautomeric forms in solution, "SH" and "NH" (Scheme 3). The selective excitation of the $\mathrm{H}_{3}$, resonance of the major 
product at $8.1 \mathrm{ppm}$ yielded positive nOe interactions with the resonances of $\mathrm{H}_{3}$ and $\mathrm{H}_{4}$ of the major product (blue labelling in Figure 1). This indicates that $\mathrm{H}_{3}$, and $\mathrm{H}_{3}$ are close in space and therefore the terpyridine may be in a structural arrangement where the outer pyridine rings are orientated with the nitrogen atoms pointing towards the terpyridine centre. In this experiment, a strong negative nOe signal at the $\mathrm{H}_{3},(8.62 \mathrm{ppm})$ resonance of the minor by-product (black labelling in Figure 1) was also observed. The origin of such signal can be explained as saturation transfer from the selective excitation of the major product resonance. Due to the saturation of this resonance, a positive nOe signal is observed from the interaction of this $\mathrm{H}_{3}$, with $\mathrm{H}_{3}$ of the same minor by-product. The fact that saturation transfer is observed under the conditions of the experiment indicates that: the two products are in slow interchange in relation to the NMR time scale explained with the two different sets of resonances observed for major and minor by-product; and there is interchange between the two products that happens faster than the experimental timescale so that saturation of the equivalent resonance in the minor terpyridine by-product is observed when selectively exciting $\mathrm{H}_{3}$, of the major product. From these observations we can tentatively assign the identities of the two products present in a $\mathrm{CDCl}_{3}$ solution of tpySH ligand as corresponding to the two possible tautomeric forms of tpySH: "SH" and "NH" form (Scheme 3). In terms of electron density of each one of the tautomeric forms, and the effect over the $\mathrm{H}_{3}$, chemical shift, we could cautiously assign the major product in the NMR spectrum to the $\mathrm{SH}$ tautomer, and the NH tautomer to the minor by-product. We would expect the structure of the NH tautomer to have a larger deshielding effect over $\mathrm{H}_{3}$, than the $\mathrm{SH}$ tautomer.

\section{Scheme 3.}

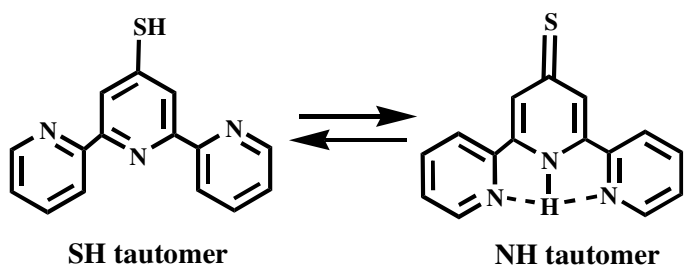

SH tautomer

NH tautomer 
1

2

3

4

5

6

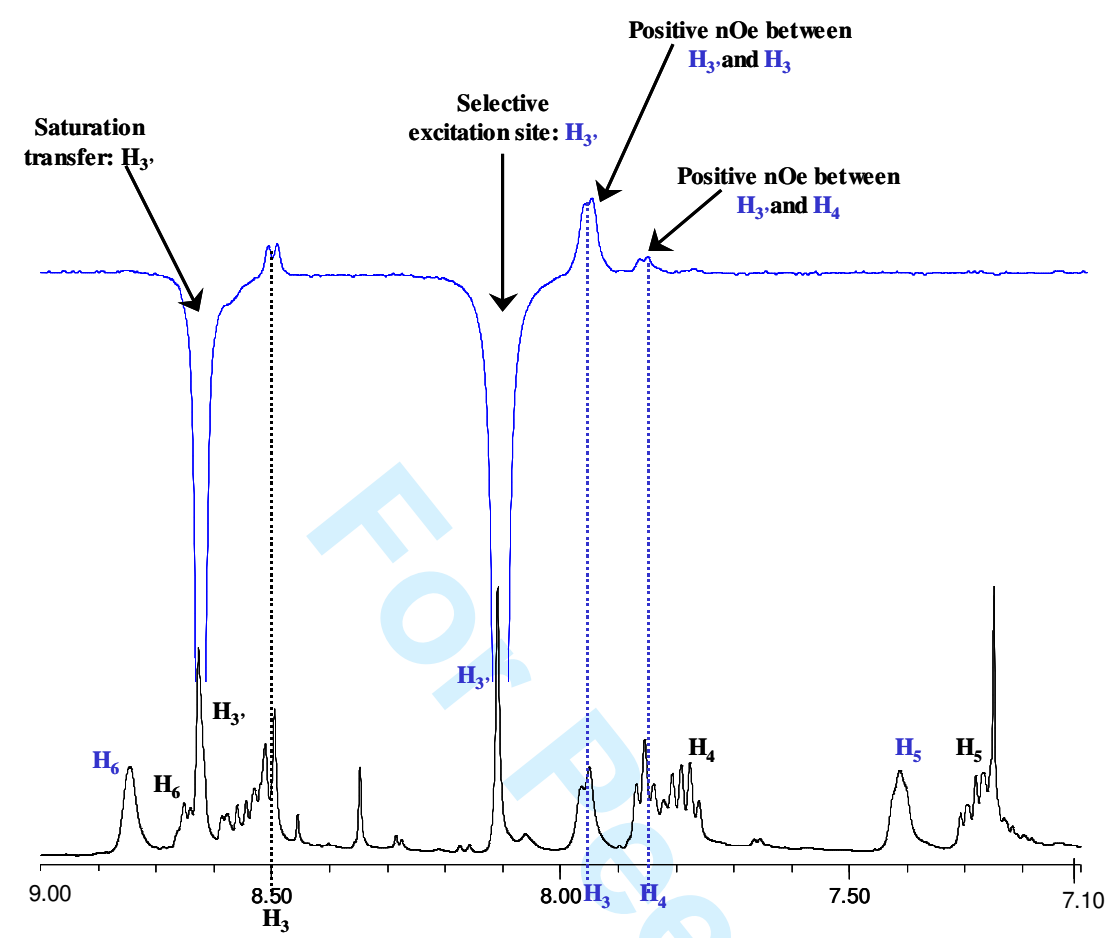

Figure 1. The $500 \mathrm{MHz}$ 1D GOESY spectrum of tpySH in $\mathrm{CDCl}_{3}$ with selective excitation of the $\mathrm{H}_{3}$, resonance at $8.11 \mathrm{ppm}$.

Similar deductions were made from the 1D GOESY spectrum recorded under the same conditions, but with selective excitation of the resonance of $\mathrm{H}_{3}$, at $8.62 \mathrm{ppm}$ for the minor by-product (Supplementary Info). In this case when exciting $\mathrm{H}_{3}$, there was also excitation of the $\mathrm{H}_{6}$ resonance (black labelling) due to overlapping of the two resonances. Positive nOe's signals towards $\mathrm{H}_{3}$ and $\mathrm{H}_{5}$ confirm the $\mathrm{NH}$ configuration, while the saturation transfer to $\mathrm{H}_{3}$, and $\mathrm{H}_{6}$ of the blue labelled terpyridine system confirms the fast exchange between the two tautomeric forms of the major and minor product.

In conclusion, the results provide evidence that the compound tpySH in a $\mathrm{CDCl}_{3}$ solution may exist in the two tautomeric forms: $\mathrm{SH}$ and NH. From the relative integration of the NMR resonances it was determined that the two tautomeric forms existed in solution in the ratio 3:2 of "SH" to "NH" forms. To further support our deductions, the shift of terpyridine protons were compared with the resonances of a model compound of the thiol tautomer, tpy- $\mathrm{SCH}_{3}$, that effectively locks the molecular structure, thereby excluding any possibility of tautomerism. The resonance of the $\mathrm{H}_{3}$, proton for tpy- $\mathrm{SCH}_{3}$ 
appeared at $8.22 \mathrm{ppm}$ in $\mathrm{CDCl}_{3} .{ }^{26}$ This resonance is comparable to that observed for the major product in the $\mathrm{CDCl}_{3}$ spectrum at $8.15 \mathrm{ppm}$ that we tentatively assigned as belonging to the $\mathrm{SH}$ tautomer. The two tautomers were also present in $d_{7}$-DMF, where the $\mathrm{N}-\mathrm{H}$ proton of the " $\mathrm{N}-\mathrm{H}$ " form was observed at $12.5 \mathrm{ppm}$.

The presence of tautomeric forms is not unusual for this type of system. A similar case is 4hydroxyterpyridine which exists in solution in two tautomeric forms, one being the enol terpyridine and the other the keto form. ${ }^{27}$ It was found that the ratio of the two tautomeric forms was dependent on the polarity and the hydrogen-bonding nature of the solvent used. Similar results were found for pyridine4-thiol; the compound exists in solution as a mixture of the thiol $(\mathrm{SH})$ and the thione $(\mathrm{NH})$ tautomeric forms. ${ }^{28}$

Single crystals of the surface-active tpySH compound were obtained in the oxidised form, tpySStpy, from a chloroform solution. The structure determination data are presented in Table 1 . The asymmetric unit contains half a molecule and the terpyridine rings are in the trans, trans conformation in the complete molecule (Figure 2). Crystal packing is shown in Figure 3.

Table 1. Crystal structure data for tpySStpy.

\begin{tabular}{|c|c|}
\hline Formula & $\mathrm{C}_{30} \mathrm{H}_{20} \mathrm{~N}_{6} \mathrm{~S}_{2}$ \\
\hline Formula weight & 528.64 \\
\hline Temperature / $\mathrm{K}$ & $296(2)$ \\
\hline Wavelength / A & 1.54178 \\
\hline Crystal system & Monoclinic \\
\hline Space group & $\mathrm{P} 2 / \mathrm{n}$ \\
\hline a / $\AA$ & $11.7585(8)$ \\
\hline $\mathrm{b} / \AA$ & $5.5378(4)$ \\
\hline $\mathrm{c} / \AA$ & $19.5665(13)$ \\
\hline$\beta /{ }^{\circ}$ & 90.528(4). \\
\hline Volume / $\AA^{3}$ & $1274.04(15)$ \\
\hline $\mathrm{Z}$ & 2 \\
\hline $\mathrm{D}_{\text {cal }} / \mathrm{Mg} / \mathrm{m}^{3}$ & 1.378 \\
\hline Absorption coefficient $/ \mathrm{mm}^{-1}$ & 2.149 \\
\hline Crystal size $/ \mathrm{mm}^{3}$ & $0.24 \times 0.04 \times 0.02$ \\
\hline Reflections collected & 7775 \\
\hline Independent reflections & 2305 \\
\hline $\mathrm{R}$ (int) & 0.0401 \\
\hline Parameters & 172 \\
\hline
\end{tabular}




\begin{tabular}{|l|l|}
\hline Goodness-of-fit on $\mathrm{F}^{2}$ & 1.039 \\
\hline $\mathrm{R} 1[\mathrm{I}>2 \sigma(\mathrm{I})]$ & 0.0403 \\
\hline wR2 & 0.0959 \\
\hline
\end{tabular}

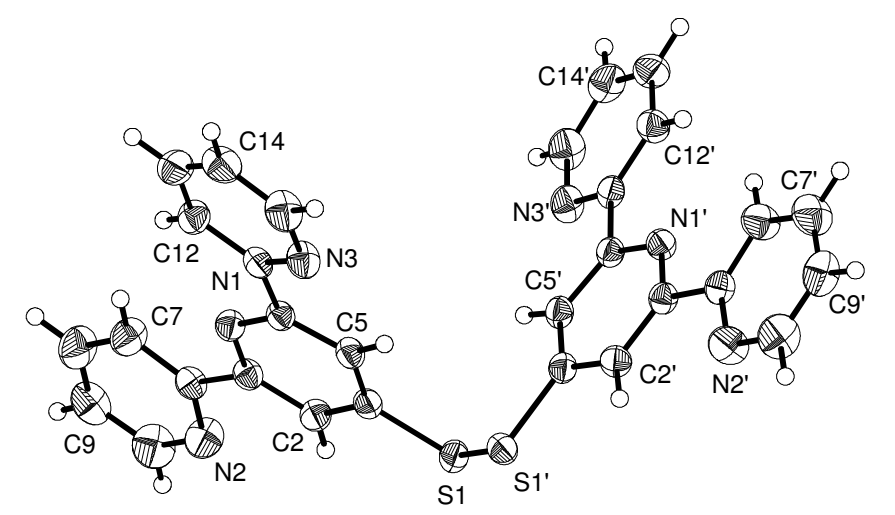

Figure 2. An ORTEP representation of the tpySStpy molecule.

Deleted: the

The sulfur-sulfur, $\mathrm{S}(1)-\mathrm{S}\left(1^{\prime}\right)$, bond length is $2.031(1) \AA$ and the $\mathrm{C}(1)-\mathrm{S}(1)$ bond length is 1.778(2) $\AA$; these values are in the same range as those reported previously for disulfide and carbon-sulfur bonds | respectively. ${ }^{29}$ The pyridine rings of the terpyridine are almost coplanar as shown by the interplanar angles (Table 2). The values obtained, indicate that the each terpyridine is almost planar. The two terpyridine groups in the molecule are almost perpendicular to each other and the torsion angle $\mathrm{C}(1)$ $\mathrm{S}(1)-\mathrm{S}\left(1^{\prime}\right)-\mathrm{C}\left(1^{\prime}\right)$ is $91.273(3)^{\circ}$.

Table 2. Interplanar angles $\left({ }^{\circ}\right)$ for planes $\mathrm{a}=\mathrm{N}(1), \mathrm{C}(1)-\mathrm{C}(5), \mathrm{b}=\mathrm{N}(2), \mathrm{C}(6)-\mathrm{C}(10)$ and $\mathrm{c}=\mathrm{N}(3)$, $\mathrm{C}(11)-\mathrm{C}(15)$.

\begin{tabular}{|l|l|l|l|}
\hline & a' & b & c \\
\hline A & 78.8 & 8.18 & 8.66 \\
\hline B & & - & 8.37 \\
\hline
\end{tabular}




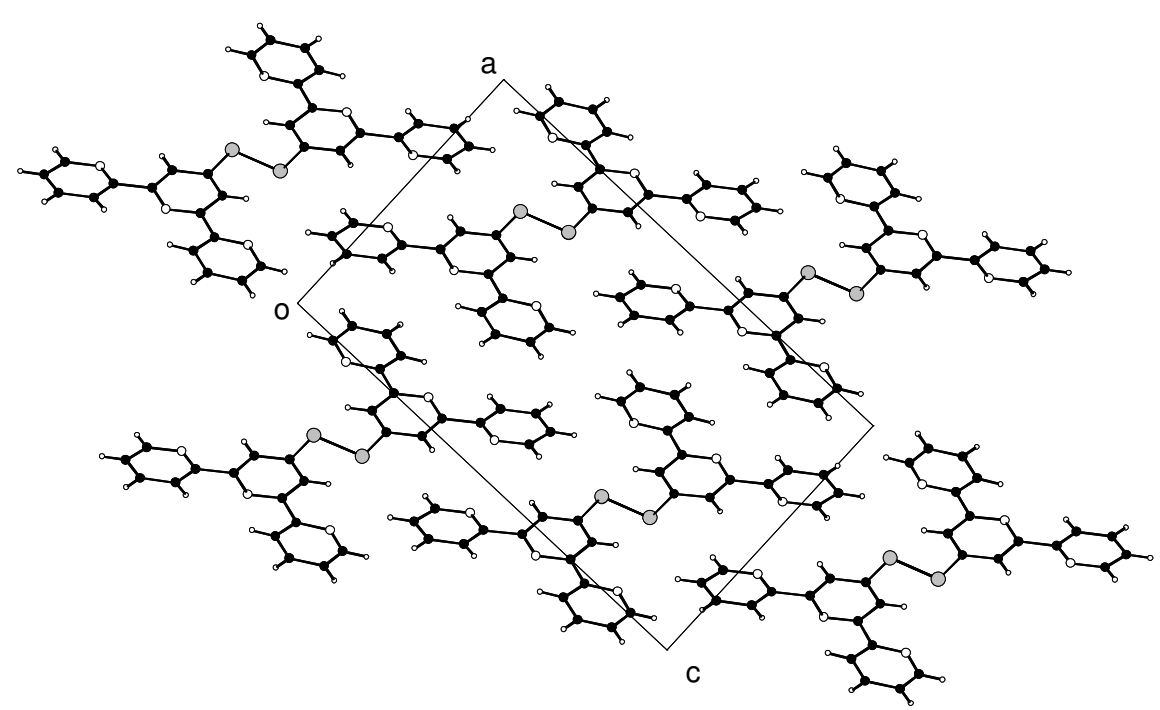

Figure 3. A view of the crystal structure down the b-axis tpySStpy.

The tpySCH $\mathrm{S}_{2}$ Stpy ligand was independently synthesized and characterised. The (+) ES MS spectra of tpySCH $\mathrm{S}_{2} \mathrm{Stpy}$ presented peaks for $\left[\mathrm{M}+\mathrm{H}^{+}\right]$and $\left[\mathrm{M}+\mathrm{Na}^{+}\right]$at $\mathrm{m} / \mathrm{z} 543$ and 565 , respectively. Peaks for fragments corresponding to tpySCH$(\mathrm{m} / \mathrm{z} 278)$ and $\left[\right.$ tpyS $\left.+\mathrm{H}^{+}\right](\mathrm{m} / \mathrm{z} 265)$ were also observed. The ${ }^{1} \mathrm{H}$ NMR spectrum presented the characteristic terpyridine resonances in the aromatic region and at 4.84 ppm the resonance for the $\mathrm{CH}_{2}$ protons of the thiol ether group. The assignments of the ${ }^{1} \mathrm{H}$ NMR and ${ }^{13} \mathrm{C}$ NMR spectra of tpySCH $\mathrm{H}_{2}$ Stpy were confirmed by HSQC (Figure 4). Cross-peaks were observed between the aromatic protons and the $\mathrm{CH}$ resonances in the ${ }^{13} \mathrm{C}$ NMR allowing the confirmation of the assignment presented above. The signal at $4.84 \mathrm{ppm}$ presented a cross peak with a carbon resonance at 34 ppm confirming that the presence of a $\mathrm{CH}_{2}$ group. 
1

2

3

4

5

6

7

8

9

10

11

12

13

14

15

16

17

18

19

20

21

22

23

24

25

26

27

28

29

30

31

32

33

34

35

36

37

38

39

40

41

42

43

44

45

46

47

48

49

50

51

52

53

54

55

56

57

58

59

60

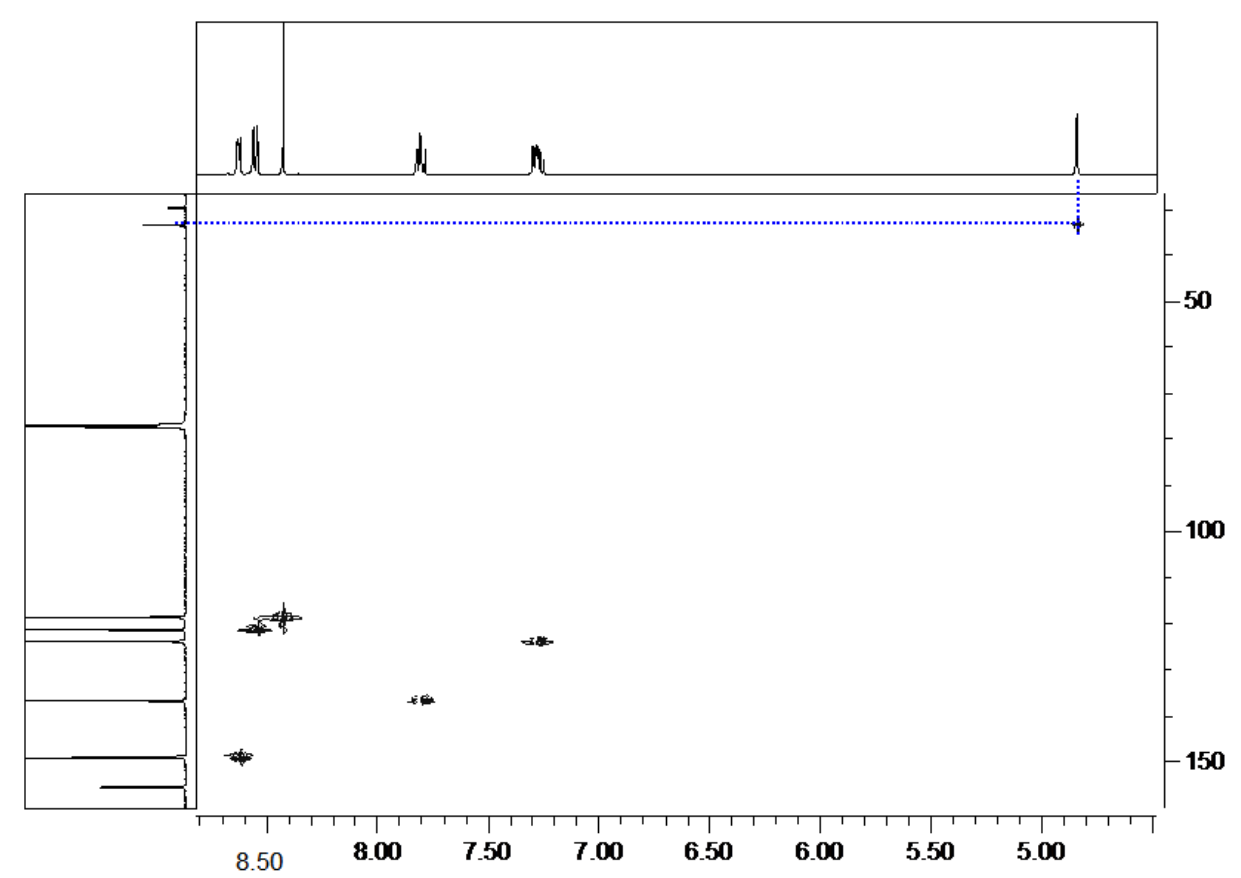

Figure 4. The $400 \mathrm{MHz}$ gradient $\mathrm{HSQC}$ spectrum for tpySCH $\mathrm{Stpy}_{2}$ in $\mathrm{CDCl}_{3}$.

\section{Synthesis of mononuclear surface-active transition metal complexes}

The surface-active ligands synthesised were used to generate transition metal complexes bearing one terpyridine with surface attachment function and one terpyridine with a cyclodextrin recognition site, such as adamantyl or biphenyl. The metal complex with an appended cyclodextrin was also prepared for surface attachment (Scheme 4).

Scheme 4. 


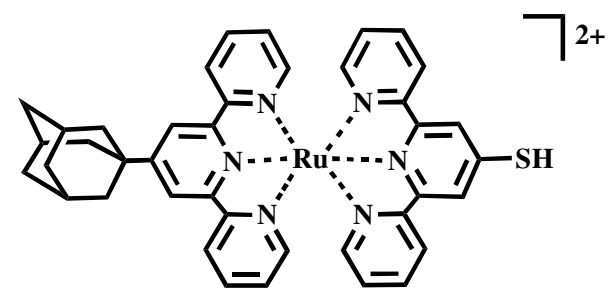

(1)

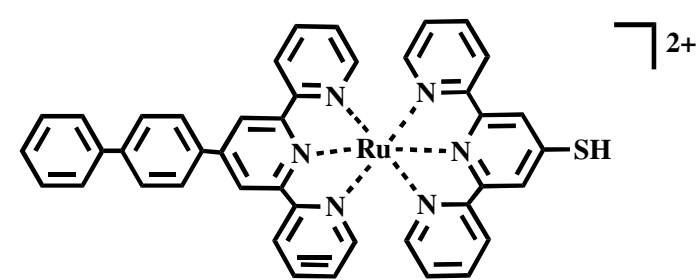

(2)

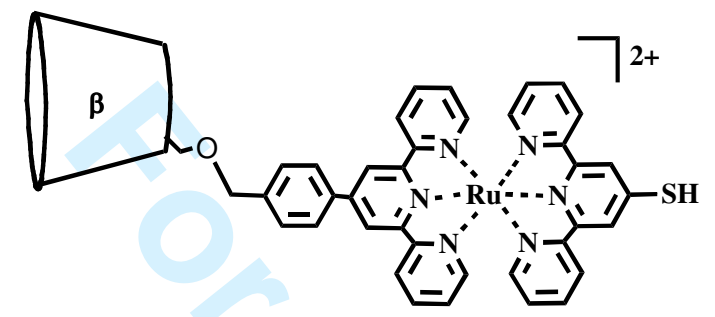

(3)

We have used established routes for ruthenium terpyridine complexes to synthesise these surface-active metalloguests. $^{30,31}$ The complexes were characterised by (+) ES-MS, NMR and absorption spectroscopy. All spectra showed $\mathrm{m} / \mathrm{z}$ signals for the loss of counter ions from the double charged species, although due to electrospray conditions they were observed as monocharged peaks. The thiol group loses a proton, leaving the sulfur atom as $\mathrm{S}^{-}$. This is not completely unexpected as the sulfurproton bond is readily cleaved or exchanged. ${ }^{24}$ The peaks observed showed the typical isotope patterns for mononuclear $\mathrm{Ru}(\mathrm{II})$ complexes. The ${ }^{1} \mathrm{H}$ NMR spectra have the characteristic resonances for 4'substituted terpyridine-based heteroleptic complexes. These comprised of different resonant peaks for the protons on positions 3 ' and 3, for both terpyridine units, along with an upfield shift to upfield of the $\mathrm{H}_{6}$ and $\mathrm{H}_{\text {tpy-6}}$ resonances in comparison with the uncomplexed ligand. A summary of the ${ }^{1} \mathrm{H}$ NMR resonances of the heteroleptic metalloguests, based on tpySH, is presented in Table 3.

Table 3. ${ }^{1} \mathrm{H}$ NMR chemical shifts of (1), (2) and (3) in $\mathrm{CD}_{3} \mathrm{CN}$.

\begin{tabular}{|c|c|c|c|}
\cline { 2 - 4 } \multicolumn{1}{c|}{} & $(\mathbf{1})$ & $\mathbf{( 2 )}$ & $\mathbf{( 3 )}$ \\
\hline $\begin{array}{c}\mathbf{H}_{3}, / \mathbf{H}_{\text {tpy-3}}, \\
(\mathrm{s}, 2 \mathrm{H})\end{array}$ & 9.05 & 8.99 & 9.18 \\
\hline $\begin{array}{c}\mathbf{H}_{3}, / \mathbf{H}_{\text {tpy-3}}, \\
(\mathrm{s}, 2 \mathrm{H})\end{array}$ & 8.93 & 8.74 & 9.09 \\
\hline
\end{tabular}


1

2

3

4

5

6

7

8

9

10

11

12

13

14

15

16

17

18

19

20

21

22

23

24

25

26

27

28

29

30

31

32

33

34

35

36

37

38

39

40

41

42

43

44

45

46

47

48

49

50

51

52

53

54

55

56

57

58

59

60

\begin{tabular}{|c|c|c|c|}
\hline $\begin{array}{c}\mathbf{H}_{\mathbf{3}} / \mathbf{H}_{\text {tpy-3}} \\
(\mathrm{d}, 2 \mathrm{H})\end{array}$ & $8.68(8.7 \mathrm{~Hz})$ & $8.71(8.2 \mathrm{~Hz})$ & $8.70(8.1 \mathrm{~Hz})$ \\
\hline $\begin{array}{c}\mathbf{H}_{\mathbf{3}} / \mathbf{H}_{\text {tpy-3}} \\
(\mathrm{d}, 2 \mathrm{H})\end{array}$ & $8.58(8.4 \mathrm{~Hz})$ & $8.65(7.5 \mathrm{~Hz})$ & $8.67(8.4 \mathrm{~Hz})$ \\
\hline $\begin{array}{c}\mathbf{H}_{\text {tpy-4}}, \mathbf{H}_{\mathbf{4}} \\
(\mathrm{m}, 4 \mathrm{H})\end{array}$ & $8.01-7.81$ & $7.97-7.89$ & $7.98-7.93$ \\
\hline $\begin{array}{c}\mathbf{H}_{\text {tpy-6}} / \mathbf{H}_{\mathbf{6}} \\
(\mathrm{d}, 2 \mathrm{H})\end{array}$ & $7.35(5.4 \mathrm{~Hz})$ & $7.55(6.5 \mathrm{~Hz})$ & $7.49(6.9 \mathrm{~Hz})$ \\
\hline $\begin{array}{c}\mathbf{H}_{\text {tpy-6}} / \mathbf{H}_{\mathbf{6}} \\
(\mathrm{d}, 2 \mathrm{H})\end{array}$ & $7.29(4.2 \mathrm{~Hz})$ & $7.44(5.7 \mathrm{~Hz})$ & $7.49(6.9 \mathrm{~Hz})$ \\
\hline $\begin{array}{c}\mathbf{H}_{\text {tpy-5}}, \mathbf{H}_{\mathbf{5}} \\
(\mathrm{m}, 4 \mathrm{H})\end{array}$ & $7.21-7.14$ & $7.21-7.16$ & $7.29-7.19$ \\
\hline $\begin{array}{c}\mathbf{H}_{\mathrm{a}} / \mathbf{H}_{\mathbf{b}} \\
(\mathrm{d}, 2 \mathrm{H})\end{array}$ & & $8.19(8.0 \mathrm{~Hz})$ & $8.34(8.4 \mathrm{~Hz})$ \\
\hline $\begin{array}{c}\mathbf{H}_{\mathbf{a}} / \mathbf{H}_{\mathbf{b}} \\
(\mathrm{d}, 2 \mathrm{H})\end{array}$ & & $7.90(8.2 \mathrm{~Hz})$ & $8.06(8.1 \mathrm{~Hz})$ \\
\hline $\begin{array}{c}\mathbf{H}_{\boldsymbol{o}} \\
(2 \mathrm{H})\end{array}$ & ------- & ------ & $7.86(7.2 \mathrm{~Hz})$ \\
\hline $\begin{array}{l}\mathbf{H}_{m}, \mathbf{H}_{p} \\
(\mathrm{~m}, 3 \mathrm{H})\end{array}$ & -.-.-. & & 7.58 \\
\hline $\begin{array}{c}\mathbf{H}_{c}, \mathbf{H}_{\boldsymbol{d}} \\
\text { (br s, 9H) }\end{array}$ & 2.30 & & ------- \\
\hline $\begin{array}{c}\mathbf{H}_{e} \\
\text { (br s, } 6 \mathrm{H})\end{array}$ & 1.97 & & ------- \\
\hline $\begin{array}{c}\mathbf{H}_{\mathrm{CD}-1} \\
\text { (br s, 7H) }\end{array}$ & ------ & 5.12 & \\
\hline $\mathbf{H}_{\mathrm{CD}-(\mathbf{2 - 6})}$ & ------- & $3.77-3.07$ & ------- \\
\hline
\end{tabular}

The UV-visible absorption spectrum of (1) in acetonitrile was recorded and showed the characteristic profile of a $\mathrm{Ru}(\mathrm{II})$ terpyridine complex. The high energy part of the spectrum is dominated by the ligand-based strong absorption bands due to $\pi-\pi^{*}$ transitions at 274 and $308 \mathrm{~nm}$. The asymmetric broad absorption band encountered in the visible region of the spectrum, centred at $490 \mathrm{~nm}$, is attributed to the spin allowed ${ }^{1}$ MLCT. The ${ }^{1}$ MLCT is red-shifted by $10 \mathrm{~nm}$ when compared with the spectrum in the same solvent for the homoleptic $\left[\mathrm{Ru}(\text { tpyada })_{2}\right]\left(\mathrm{PF}_{6}\right)_{2}\left(\lambda_{\mathrm{MLCT}}=480 \mathrm{~nm}\right)$. This could be

URL: http:/mc.manuscriptcentral.com/tandf/gsch Email: suprachem@mail.cm.utexas.edu 
explained by the electron-withdrawing properties of the thiol group in the 4' position of the terpyridine, stabilising the ${ }^{1}$ MLCT excited state. ${ }^{30}$

\section{Synthesis of the $R u($ II) dinuclear complexes}

The $\mathrm{Ru}(\mathrm{II})$ complexes were synthesised by reacting two equivalents of $[\mathrm{Ru}(\mathrm{R}-\mathrm{tpy})] \mathrm{Cl}_{3}$ with the bisterpyridine ligand, tpySCH $\mathrm{S}_{2} \mathrm{Stpy}$ (Scheme 5). ES-MS spectra for the $\mathrm{Ru}$ (II) dinuclear complexes were recorded and showed the characteristic $\mathrm{m} / \mathrm{z}$ signals for the loss of counter ions. The complexes showed $\mathrm{m} / \mathrm{z}$ signals corresponding to the doubly and triply-charged species. The NMR spectra of the complexes revealed symmetry around the central sulfur bridge. The ${ }^{1} \mathrm{H}$ NMR spectrum of (4) showed resonances characteristic for a heteroleptic metal complex based on 4'-substituted terpyridines. The expected ${ }^{1} \mathrm{H}$ NMR shifts of 4 '-substituted terpyridines upon complexation with $\mathrm{Ru}(\mathrm{II})$ were present: $\mathrm{H}_{6}$ and $\mathrm{H}_{\text {tpy- } 6}$ peaks at 7.49 and $7.44 \mathrm{ppm}$ showed an upfield shift upon metal complexation. The presence of two resonant signals at 8.99 and $8.90 \mathrm{ppm}$, for the $\mathrm{H}_{3}$, and $\mathrm{H}_{\text {tpy-3 }}$, protons, indicated that the terpyridines have different substituents. The same effect was also observed for protons on positions 3 and 6, which presented different chemical shifts for the two terpyridines. The resonance for $\mathrm{H}_{3}$ and $\mathrm{H}_{\text {tpy-3 }}$ appeared as two partially overlapped doublets at 8.67 and $8.65 \mathrm{ppm}$. The singlet, assigned to the $\mathrm{CH}_{3}$ resonance at $2.53 \mathrm{ppm}$, and the $\mathrm{S}-\mathrm{CH}_{2}-\mathrm{S}$ singlet at $5.65 \mathrm{ppm}$, dominated the aliphatic region of the spectrum. The relative integration of the resonances in the aromatic region with the central $\mathrm{CH}_{2}$ was 2:1, indicating symmetry around the $\mathrm{CH}_{2}$ group. The $\mathrm{CH}_{2}$ resonance was shifted downfield by $0.8 \mathrm{ppm}$ in comparison with uncomplexed tpySCH $\mathrm{S}_{2} \mathrm{Stpy}$ ( $4.84 \mathrm{ppm}$ ). The introduction of a positive charge with the metal centre induces the deshielding of these protons by alteration of the electronic environment around the sulfur atom. The assignments were confirmed by HSQC spectroscopy, particularly in assigning the $\mathrm{CH}_{2}$ resonance for the dinuclear complexes.

\section{Scheme 5.}


(4)
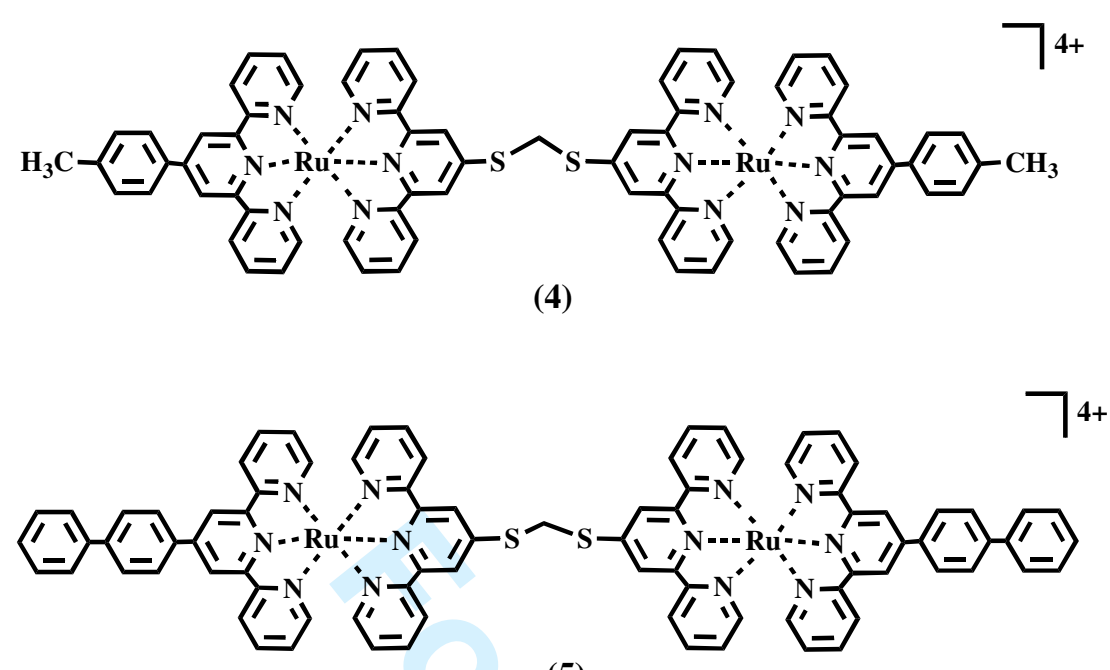

(5)

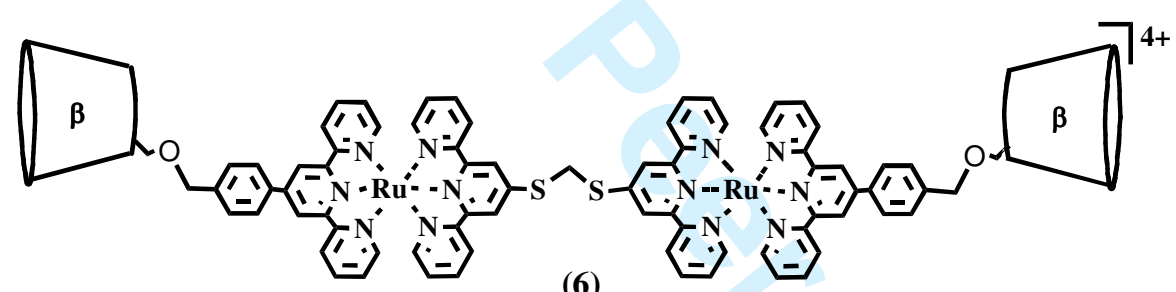

The ${ }^{1} \mathrm{H}$ NMR resonances for the synthesised dinuclear Ru(II) complexes are summarised in Table 4.

Table 4. ${ }^{1} \mathrm{H}$ NMR chemical shifts of the dinuclear $\mathrm{Ru}(\mathrm{II})$ complexes of tpySCH $\mathrm{SCH}_{2} \mathrm{Stpy}$ in $\mathrm{CD}_{3} \mathrm{CN}$.

\begin{tabular}{|c|c|c|c|}
\hline & (4) & (5) & (6) \\
\hline $\begin{array}{c}\mathbf{H}_{3^{\prime}} / \mathbf{H}_{\text {tpy-3} \cdot} \\
(\mathrm{s}, 4 \mathrm{H})\end{array}$ & 9.00 & 8.99 & 9.29 \\
\hline $\begin{array}{c}\mathbf{H}_{\mathbf{3}}, / \mathbf{H}_{\text {tpy-3}}, \\
(\mathrm{s}, 4 \mathrm{H})\end{array}$ & 8.92 & 8.90 & 9.09 \\
\hline $\begin{array}{c}\mathbf{H}_{3} / \mathbf{H}_{\text {tpy-3 }} \\
(\mathrm{d}, 4 \mathrm{H})\end{array}$ & $8.66(8.1 \mathrm{~Hz})$ & $8.67(8.4 \mathrm{~Hz})$ & $8.99(7.8 \mathrm{~Hz})$ \\
\hline $\begin{array}{c}\mathbf{H}_{3} / \mathbf{H}_{\text {tpy-3}} \\
(\mathrm{d}, 4 \mathrm{H})\end{array}$ & ------ & $8.65(7.8 \mathrm{~Hz})$ & $8.69(8.1 \mathrm{~Hz})$ \\
\hline $\begin{array}{c}\mathbf{H}_{\mathrm{tpy}-4}, \mathbf{H}_{\mathbf{4}} \\
(\mathrm{m}, 8 \mathrm{H})\end{array}$ & $7.97-7.93$ & $7.97-7.89$ & $7.97-7.89$ \\
\hline$H_{\text {tpy- } 6} / H_{6}$ & $7.50-7.43$ & $7.49(6.0 \mathrm{~Hz})$ & $7.50(6.9 \mathrm{~Hz})$ \\
\hline
\end{tabular}




\begin{tabular}{|c|c|c|c|}
\hline$(\mathrm{d}, 4 \mathrm{H})$ & & & \\
\hline $\begin{array}{c}\mathbf{H}_{\text {tpy-6}} / \mathbf{H}_{\mathbf{6}} \\
(\mathrm{d}, 4 \mathrm{H})\end{array}$ & ------- & $7.44(5.6 \mathrm{~Hz})$ & $7.45(4.5 \mathrm{~Hz})$ \\
\hline $\begin{array}{c}\mathbf{H}_{\text {tpy-5}}, \mathbf{H}_{\mathbf{5}} \\
(\mathrm{m}, 8 \mathrm{H})\end{array}$ & $7.25-7.17$ & $7.23-7.16$ & $7.24-7.16$ \\
\hline $\begin{array}{c}\mathbf{H}_{\mathbf{a}} / \mathbf{H}_{\mathbf{b}} \\
(\mathrm{d}, 4 \mathrm{H})\end{array}$ & $8.20(8.1 \mathrm{~Hz})$ & $8.11(8.4 \mathrm{~Hz})$ & $8.33(8.4 \mathrm{~Hz})$ \\
\hline $\begin{array}{c}\mathbf{H}_{\mathbf{a}} / \mathbf{H}_{\mathbf{b}} \\
(\mathrm{d}, 4 \mathrm{H})\end{array}$ & $7.74(7.8 \mathrm{~Hz})$ & $7.58(8.0 \mathrm{~Hz})$ & $8.06(8.7 \mathrm{~Hz})$ \\
\hline $\begin{array}{c}\mathbf{H}_{o} \\
(4 \mathrm{H})\end{array}$ & & ------- & $7.86(7.2 \mathrm{~Hz})$ \\
\hline $\begin{array}{c}\mathbf{H}_{m}, \mathbf{H}_{p} \\
(\mathrm{t}, 6 \mathrm{H})\end{array}$ & & ------- & $7.58(7.2 \mathrm{~Hz})$ \\
\hline $\begin{array}{c}\mathbf{H}_{c}, \mathbf{H}_{d} \\
(\mathrm{br} \mathrm{s}, 18 \mathrm{H})\end{array}$ & & --- & -----. \\
\hline $\begin{array}{c}\mathbf{H}_{e} \\
\text { (br s, 12H) }\end{array}$ & $=-$ & - & -------- \\
\hline $\begin{array}{c}\mathbf{H}_{\mathbf{C D}-\mathbf{1}} \\
\text { (br s, 14H) }\end{array}$ & 5.20 & & ------- \\
\hline $\mathbf{H}_{\mathrm{CD}-(2-6)}$ & $3.82-3.08$ & ------- & ------- \\
\hline $\mathrm{S}-\mathrm{CH}_{2}-\mathrm{S}$ & 4.73 & 5.65 & 6.06 \\
\hline
\end{tabular}

\section{Photophysical properties of the Ru(II) dinuclear complexes}

The UV-visible absorption spectrum of (4) showed the $\pi-\pi^{*}$ ligand centred absorption bands at 287 and $307 \mathrm{~nm}$ and the MLCT band at $\lambda=494 \mathrm{~nm}$. Upon excitation of the ${ }^{1}$ MLCT, luminescence from the ${ }^{3}$ MLCT was observed at $\lambda_{\text {ems }}=638 \mathrm{~nm}$ (Figure 5). The luminescence relative quantum yield in acetonitrile was determined to be $2.0 \times 10^{-4}$, which is about six times larger than the value of $3.2 \times 10^{-5}$ reported ${ }^{30}$ for $\left[\operatorname{Ru}(\operatorname{ttp})_{2}\right]^{+2}$. 

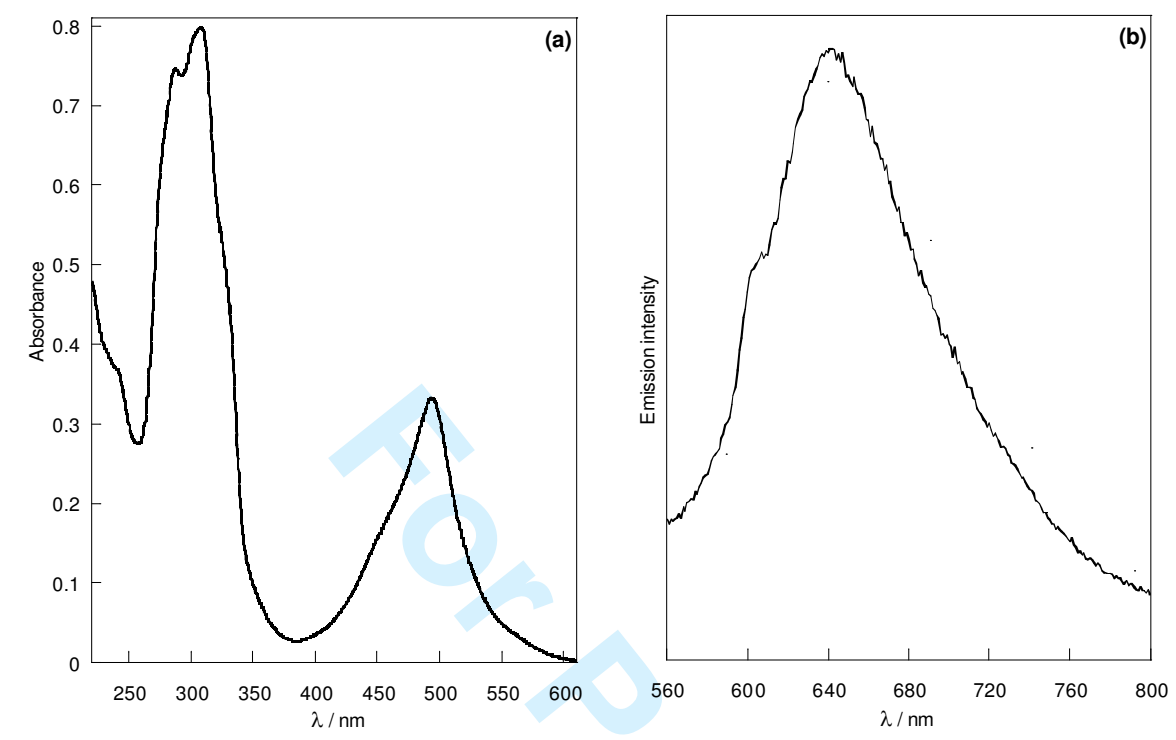

Figure 5. (a) UV-visible absorption and (b) emission spectra of (4) $\lambda_{\text {exc }}=470 \mathrm{~nm}$. The emission spectrum is corrected for the PMT response. Both spectra were recorded in acetonitrile solution.

The photophysical properties of (5) were investigated. The UV region of the spectrum presented strong absorbance bands arising from the $\pi-\pi^{*}$ ligand based transitions centred at 287 and $310 \mathrm{~nm}$. The visible region of the spectrum is dominated by the charge transfer band ( ${ }^{1}$ MLCT) centred at $495 \mathrm{~nm}, \varepsilon$ $=8.15 \times 10^{4} \mathrm{~cm}^{-1} \mathrm{M}^{-1}$. The model mononuclear $\left[\mathrm{Ru}(\text { biptpy })_{2}\right]^{+2}$ complex has been reported to have ${ }^{1}$ MLCT centred at $494 \mathrm{~nm}^{32}$ with $\varepsilon=4.5 \times 10^{4} \mathrm{~cm}^{-1} \mathrm{M}^{-1}$, which is approximately half the value for the dinuclear complex. 

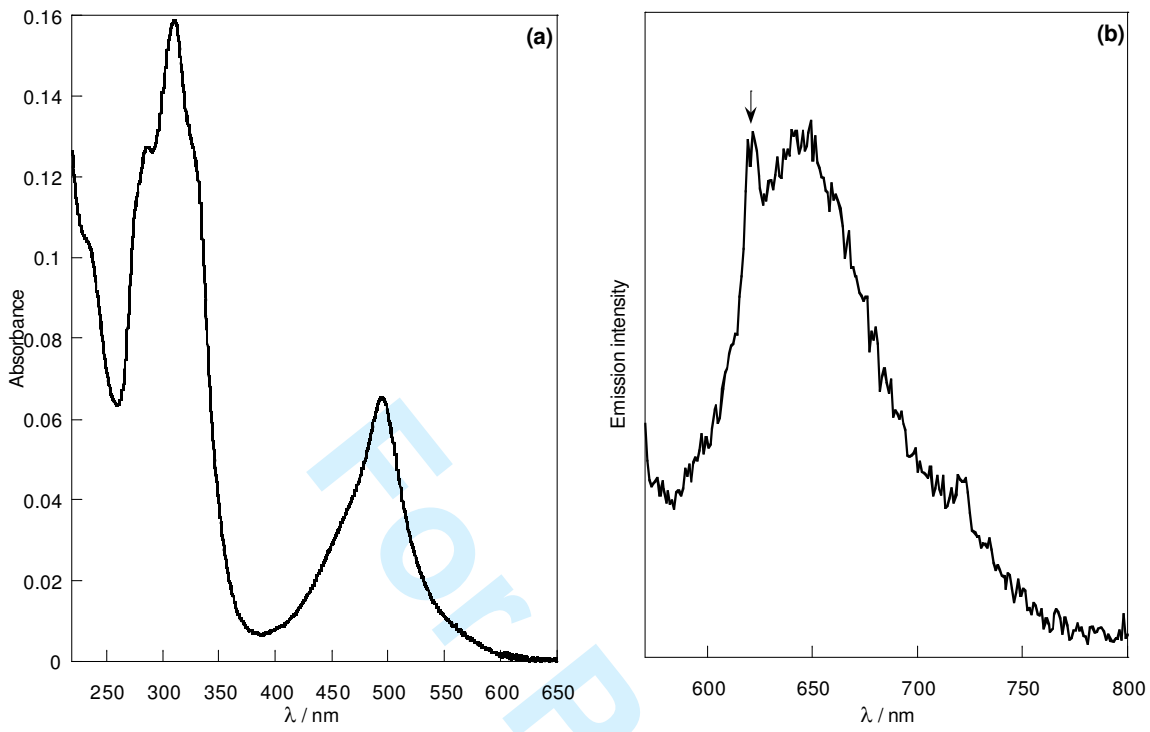

Figure 6. (a) UV-visible absorption and (b) emission spectra of (5), $\lambda_{\mathrm{exc}}=495 \mathrm{~nm}$. The emission spectrum was corrected for PMT response. Both spectra were obtained for acetonitrile solutions of the complex. The peak indicated by the arrow is due to scattering.

Upon excitation at $\lambda_{\mathrm{exc}}=495 \mathrm{~nm}$, luminescence was detected at $645 \mathrm{~nm}$ (Figure 6). The maximum of the emission is slightly shifted to the red in comparison with that observed for (4).This is due to the increase in the $\pi$-accepting nature of the biptpy tail in comparison with the tolyl group of the previous complex. $^{30}$ The luminescence relative quantum yield for this complex in acetonitrile was measured as $1.5 \times 10^{-4}$.

\section{Electrochemistry studies for Ru(II) thio-based surface-active metalloguest}

Monolayer of the complex (1) were formed on indium tin oxide (ITO) electrodes and studied by cyclic Deleted: Au, Pt and voltammetry, ITO proved to be the optimal surface for forming the monolayers, as evidenced by the Deleted: $\mathrm{h}$ most clean voltammetric responses. An ITO electrode with an area of $0.24 \mathrm{~cm}^{2}$ was used to adsorb the

Deleted: 
$\mathrm{Ru}$ (II) sulfur based complex from solutions containing $2 \mathrm{mM}$ of the complex in order to form monolayer. Voltammetric measurements of the films formed were carried out in anhydrous acetonitrile, and a clear reversible process was evident (Figure 7). A well defined and reversible response was observed for all scan rates up to $2 \mathrm{~V} \mathrm{~s}^{-1}$. The anodic peak for the oxidation of the $\mathrm{Ru}$ (II) complex occurred at ca. $1 \mathrm{~V}$ ( $v s$ $\left.\mathrm{Ag} / \mathrm{Ag}^{+}\right)$whereas the reduction peak occurred at ca. $0.95 \mathrm{~V}$ : these values of the redox peaks are similar to those reported for $\mathrm{Ru}(\mathrm{bpy})_{3}{ }^{2+33}$. The peak-peak separation $\left(\Delta \mathrm{E}_{\mathrm{p}}=\mathrm{E}_{\mathrm{p}}{ }^{\mathrm{f}}-\mathrm{E}_{\mathrm{p}}{ }^{\mathrm{b}}\right.$, where $\mathrm{E}_{\mathrm{p}_{-}}{ }^{\mathrm{f}}$ and $\mathrm{E}_{\mathrm{p}}{ }^{\mathrm{b}}$ are the peak potentials for the forward and back scans) were found to be ca. $50 \mathrm{mV}$ at $v=500 \mathrm{mV} \mathrm{s}^{-1}$ and increased with the scan rate. The fact the peak separation is lower than $59 \mathrm{mV}$ is indicative of a contribution from a surface- confined species, indicating adsorption onto the surface ${ }^{34}$. The most striking evidence of a surface process is that the peak current scales linearly with scan rate. As experiments were carried out in a solution that did not contain the complex, there is no contribution to the current from diffusive process ${ }^{34}$. The stability of the monolayer under these conditions was investigated further, as reported below.

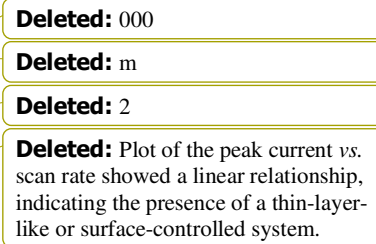

Deleted: Plot of the peak current $v s$. scan rate showed a linear relationship, indicating the presence of a thin-layerlike or surface-controlled system.

Formatted: Superscript

Formatted: Superscript 


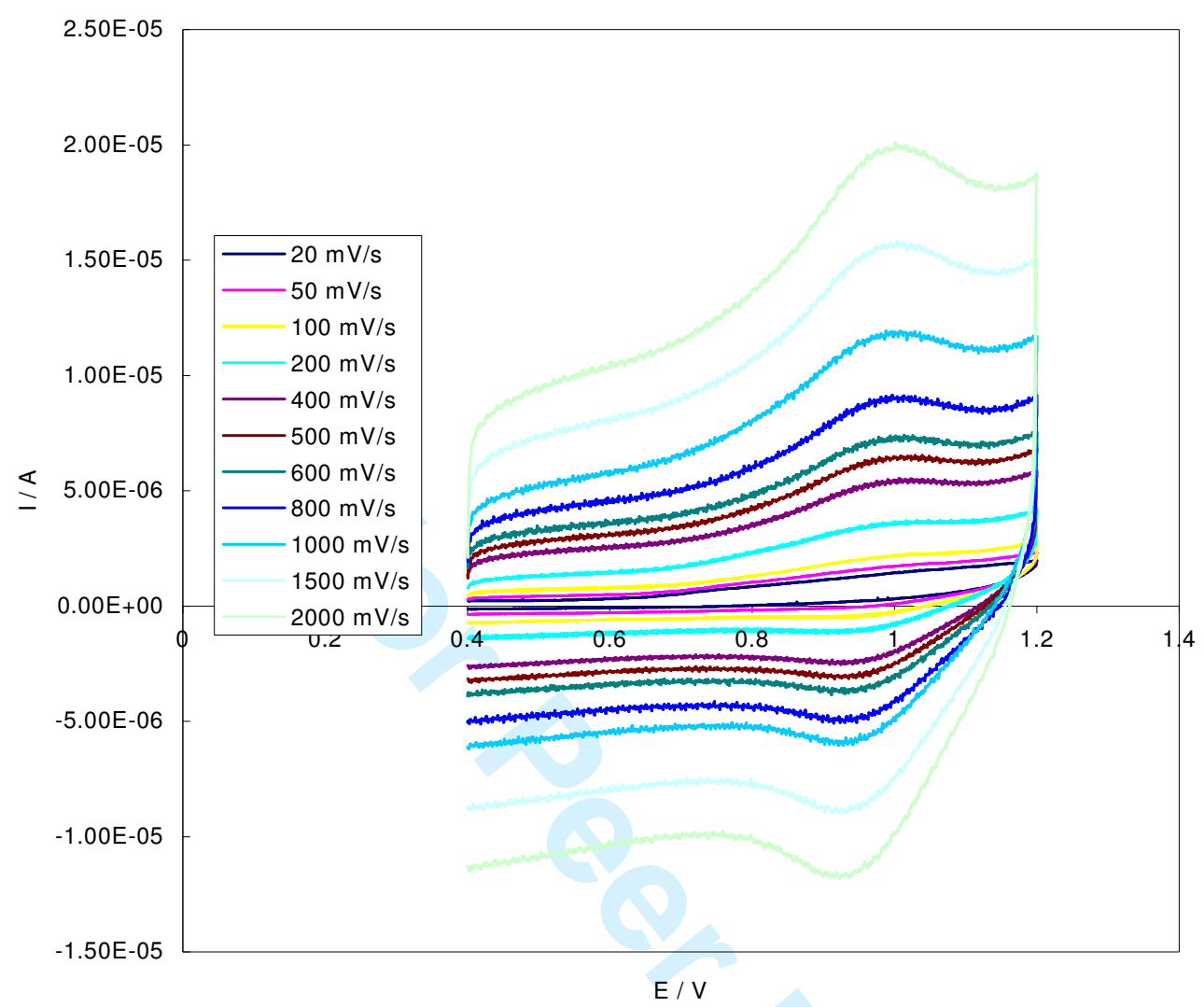

Figure 7. $\mathrm{CVs}$ of a $[\mathrm{Ru}$ (tpyada) $($ tpySH$)]\left(\mathrm{PF}_{6}\right)_{2} \mathrm{SAM}$ on an ITO electrode in acetonitrile, $0.1 \mathrm{M}$ $\mathrm{TBAPF}_{6}$ as supporting electrolyte at different scan rates.

Consecutives cycles at the same scan rate were performed and the change in the resulting CV was monitored. This experiment was performed for 50, 600 and $1000 \mathrm{mV} \mathrm{s}^{-1}$ scan rates. Similar observations were made for the three sets of independent experiments and, as an example, the results | obtained for the $1000 \mathrm{mV} \mathrm{s}^{-1}$ scan rate are considered (Figure 8). In this case, it is clear that the CV response is highly reversible over time, but that there is a small decrease in the peak current, with each scan. By integrating $i-V$ characteristics, the charge and surface coverage can be obtained (Table 5). 


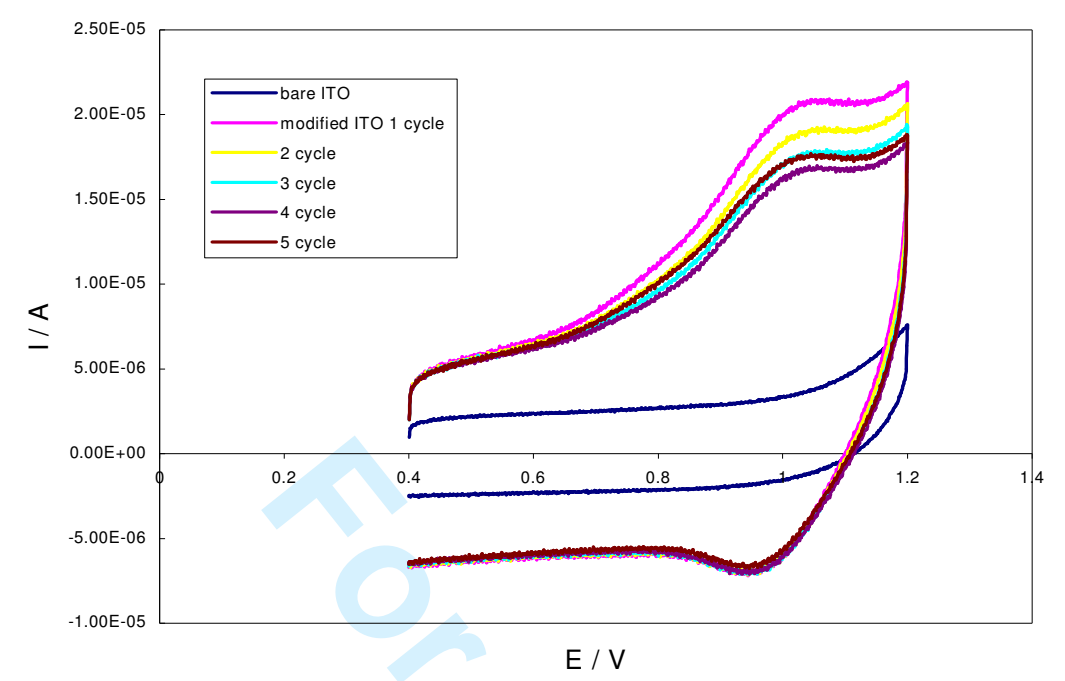

Figure 8. $\mathrm{CVs}$ of a $[\mathrm{Ru}($ tpyada $)($ tpySH$)]\left(\mathrm{PF}_{6}\right)_{2} \mathrm{SAM}(\mathrm{c}=2 \mathrm{mM})$ on a ITO electrode in acetonitrile, 0.1

$\mathrm{M} \mathrm{TBAPF}_{6}$ as supporting electrolyte with continuous cycling at $1000 \mathrm{mV} \mathrm{s}^{-1}$.

Table 5. Variation of the charge and surface coverage with increase number of cycles.

\begin{tabular}{|c|c|c||}
\hline Cycle number & Charge $/ \mathbf{1 0}^{-\mathbf{7}}(\mathbf{C})$ & $\Gamma / \mathbf{1 0}^{-\mathbf{1 1}}\left(\mathbf{m o l} \mathbf{~ c m}^{-\mathbf{2}}\right)$ \\
\hline 1 & 9.36 & 4.04 \\
\hline 2 & 8.83 & 3.81 \\
\hline 3 & 8.43 & 3.64 \\
\hline 4 & 8.12 & 3.51 \\
\hline 5 & 7.96 & 3.44 \\
\hline 6 & 7.45 & 3.22 \\
\hline \hline
\end{tabular}

The decrease observed in surface coverage with increase number of cycles is indicative of some loss of electroactive species adsorbed in the ITO electrode. Nonetheless, the surface coverages for these large complexes are reasonable and it is clear that [Ru(tpyada)(tpySH) $]\left(\mathrm{PF}_{6}\right)_{2}$ electroactive SAMs can be formed on an ITO electrode surface.

\section{Conclusions}

We have prepared $\mathrm{Ru}$ (II) surface active complexes with appended guest and host moieties for the development of supramolecular wires on surfaces and examined the electrochemical properties of a 
$\mathrm{Ru}(\mathrm{II})$ surface active guest. Monolayers of the complex show promising electrochemical behaviour. The tpySH ligand proved a versatile motif for surface attachment and we have explored the tautomerism properties that may affect its surface binding studies. A ligand for dinuclear complexes was prepared and the dinuclear $\mathrm{Ru}(\mathrm{II})$ complexes were investigated. The complexes show interesting photophysical properties which may lead to further studies in solution assembly of metallocyclodextrins-metalloguests.

\section{Supplementary material includes NMR spectra. Crystallographic data are deposited at the Cambridge} Crystallographic Data Centre CDC 611415.

Acknowledgement

Financial support from the Marie Curie Research Training Network grant "UNI-NANOCUPS" (MRTN-CT-2003-504233) is appreciated, P.B greatly acknowledges support via a Marie Curie IntraEuropean Fellowship (MEIF-CT-2005-515356) under the $6_{\text {th }}^{\text {th }}$ European Community Framework Programme. We also wish to acknowledge COST-D31 action and the Aventis Foundation for support (MJJPS).

\section{Experimental}

\section{Materials and Instrumentation}

All starting materials were purchased from Aldrich unless otherwise indicated. Solvents used in synthetic procedures were analytical grade with the exception of HPLC grade solvents used in spectroscopic studies. Double deionised water was used where necessary in the spectroscopic studies. All the ligand synthetic procedures were carried out under nitrogen atmosphere. Thin layer chromatography (TLC) analyses were performed on either Merck silica gel 60 aluminium plates or Merck alumina Brockman I grade, as indicated. $\mathrm{RuCl}_{3} \cdot 3 \mathrm{H}_{2} \mathrm{O}$ was kindly supplied from Johnson \& Matthey.

The synthesis of 4'-(1-adamantyl)-2,2': 6', 2"-terpyridine (tpyada), 4'-tolyl-2,2': 6', 2"-terpyridine (ttp) and 4'-(4-biphenyl)-2,2': 6', 2"-terpyridine (biptpy), pm- $\beta-\mathrm{CD}(\mathrm{ttp})$ were prepared by published methods.REF

NMR spectra were recorded on Bruker AC 300, AV 300 and DRX 500. Electrospray mass spectra were recorded on a Micromass LC-TOF machine. Elemental analyses were recorded on a Carlo Erber EA1110 simultaneous CHNS elemental analyser at the University of Birmingham.

Single Crystal X-Ray diffraction data was collected at 296 K on a Brüker Smart 6000 diffractometer equipped with a CCD detector and a copper tube source. Structures were solved and refined using SHELXL ${ }^{35}$ Absorption spectra were recorded on a Shimadzu UV-3101PC UV-Vis-NIR scanning

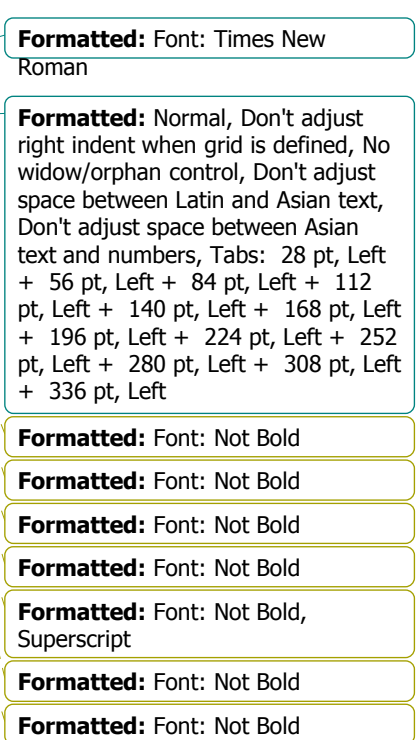

Deleted: ${ }^{34}$ 
spectrometer. Emission spectra were recorded on a Photon Technology International QM-1 steady state spectrometer employed with a dual grating 500/750 nm emission monochromator. Quantum yields were determined using the "optical dilute relative method" 36 using $\left[\mathrm{Ru}\left(2,2^{\prime} \text {-bipyridyl }\right)_{3}\right] \mathrm{Cl}_{2}$ as a reference with $\Phi=0.028$ in aerated $\mathrm{H}_{2} \mathrm{O} \cdot \frac{37}{\nabla}$ The GOESY or one-dimensional gradient NOE spectroscopy spectrum was recorded at $27^{\circ} \mathrm{C}$ using a Bruker DRX 500 with 7 seconds relaxation delay and $5 \mathrm{~Hz}$ of selective excitation. Each spectrum was obtained as accumulation of 512 scans.

\section{Formation of self-assembled monolayers (SAMs)}

Spontaneously adsorbed monolayers were formed upon immersion of the ITO electrode in solutions of the complex in acetonitrile at the concentrations between 1-5 mM for 24 hours. Before electrochemical measurements were made, the electrodes were rinsed with acetonitrile in order to remove any unbound material. Subsequent measurements were performed in blank electrolyte containing $0.1 \mathrm{M} \mathrm{TBAPF}_{6}$ as supporting electrolyte

\section{Electrochemistry}

Cyclic voltammograms were recorded using an electrochemical analyzer $(\mathrm{CH}$ Instruments, model CHI730A). A typical three electrode configuration was used, where the working electrode was an ITO coated glass plate on which the SAM film was deposited, a platinum coil was used as counter electrode. Potentials are all referenced against a nonaqueous $\mathrm{Ag} / \mathrm{Ag}^{+}$reference containing $5 \times 10^{-3} \mathrm{M}$ $\mathrm{Ag}\left(\mathrm{NO}_{3}\right)$ The area of the working electrode was kept constant (typically between $\left.0.2-0.3 \mathrm{~cm}^{2}\right)$ during all measurements.

The surface coverage calculated is based on the measurement of $\mathrm{Q}$, the charge passed to electrolyse the electroactive sites. A definition of $\Gamma$ is given by the equation:

$$
\Gamma \equiv \frac{Q}{n F A}
$$

where $\mathrm{n}$ is the number of electrons transferred; $\mathrm{F}$ is the Faraday's constant and $\mathrm{A}$ is the electrode area.

\section{4'-(mercapto)-2,2': 6', 2''-terpyridine (tpySH)}

A solution of tpy-Cl (1.01 g; $3.78 \mathrm{mmol})$ and $\mathrm{NaSCH}_{2} \mathrm{CH}_{3}, 90 \%$ pure $(1.64 \mathrm{~g} ; 1.95 \mathrm{mmol})$ in dry DMF $(20 \mathrm{~mL})$ was heated to $150{ }^{\circ} \mathrm{C}$ in a

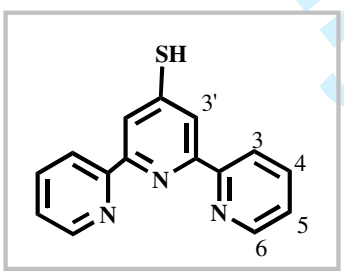


silicone oil bath for 6 hours. A mixture of a yellow solution with a white solid was obtained. The reaction was filtered and after evaporation of the filtrate a yellow solid was obtained. The yellow solid was redissolved in acetone that upon evaporation yielded an oil. Upon addition of ether the precipitation of an off-white solid was achieved and was collected by filtration and washed with ether yielding $0.20 \mathrm{~g}(20 \%)$. The solid was treated with hydrazine monohydrate $(0.5 \mathrm{~mL})$ in a methanol/pyridine (1:1) solution to produce the free thiol ligand.

${ }^{1} \mathrm{H}-\mathrm{NMR}\left(300 \mathrm{MHz},\left(\mathrm{CD}_{3}\right)_{2} \mathrm{CO}\right): \delta$ in ppm $8.63\left(\mathrm{~d}, 2 \mathrm{H}, \mathrm{H}_{6}, J=5.7 \mathrm{~Hz}\right) ; 8.28\left(\mathrm{~d}, 2 \mathrm{H}, \mathrm{H}_{3}, J=8.1 \mathrm{~Hz}\right)$; $8.16\left(\mathrm{~s}, 2 \mathrm{H}, \mathrm{H}_{3}\right) ; 7.89\left(\mathrm{td}, 2 \mathrm{H}, \mathrm{H}_{4}, J=7.5 \mathrm{~Hz}, J=1.8 \mathrm{~Hz}\right) ; 7.32\left(\mathrm{ddd}, 2 \mathrm{H}, \mathrm{H}_{5}, J=7.5 \mathrm{~Hz}, J=4.8 \mathrm{~Hz}, J\right.$ $=1.2 \mathrm{~Hz}) .{ }^{13} \mathrm{C}$ NMR $\left(75 \mathrm{MHz}, \mathrm{CD}_{3} \mathrm{Cl}\right): \delta$ in ppm 156, 155, 149.7, 146.7, 138, 126, 121, 117

ES-MS (+) $m / z: 288[\mathrm{M}+\mathrm{Na}]^{+} ; 266[\mathrm{M}+\mathrm{H}]^{+}$. Anal. Found: C, 67.94; H, 4.16; N, 15.82. Calcd for $\left(\mathrm{C}_{15} \mathrm{H}_{11} \mathrm{~N}_{3} \mathrm{~S}\right)$ : C, 67.90; H, 4.18; N, 15.84. UV-Vis in $\mathrm{CH}_{3} \mathrm{OH}: \lambda_{\max }$ in $\mathrm{nm}\left(\varepsilon\right.$ in $\left.\mathrm{M}^{-1} \mathrm{~cm}^{-1}\right) 280$ (20190); 300 (17550); 312 (15160); 386 (8645).

\section{bis(4'-(mercapto)-2,2': 6', 2'-terpyridyl)methane (tpySCH $\mathrm{CH}_{2} \mathrm{Stpy)}$}

In a two neck flask tpy- $\mathrm{Cl}(0.55 \mathrm{~g}, 2.06 \mathrm{mmol})$ and an excess of $\mathrm{NaSCH}_{2} \mathrm{CH}_{3}(0.87 \mathrm{~g} ; 10.3 \mathrm{mmol})$ were added. After the addition of 15 $\mathrm{mL}$ of dry DMF a yellow suspension was formed. The solution was refluxed for 30 hours with the aid of a heating mantel. The solution colour changed to dark orange. The solvent volume was reduced to one third and $50 \mathrm{~mL}$ of $0.1 \mathrm{~N} \mathrm{HCl}$ were added precipitating an off white

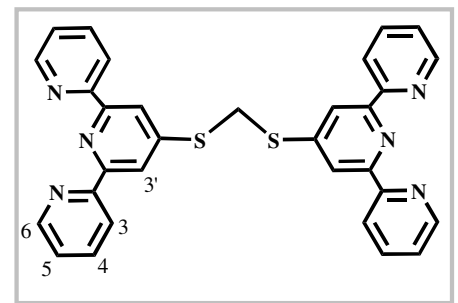
solid. The solid was collected by suction filtration and then redissolved in $\mathrm{CHCl}_{3}$ and washed with water $(3 \times 30 \mathrm{~mL})$. The combined organic layers were dried over anhydrous $\mathrm{NaSO}_{4}$ followed by filtration. Evaporation of the solvent lead to $0.23 \mathrm{~g}$ of the product tpySCH $\mathrm{H}_{2} \mathrm{Stpy}(25 \%)$. ${ }^{1} \mathrm{H}-\mathrm{NMR}(400$ $\left.\mathrm{MHz}, \mathrm{CD}_{3} \mathrm{Cl}\right)$ : $\delta$ in ppm $8.63\left(\mathrm{~d}, 4 \mathrm{H}, \mathrm{H}_{6}, J=4.8 \mathrm{~Hz}\right) ; 8.55\left(\mathrm{~d}, 4 \mathrm{H}, \mathrm{H}_{3}, J=8.0 \mathrm{~Hz}\right) ; 8.43\left(\mathrm{~s}, 4 \mathrm{H}, \mathrm{H}_{3},\right)$; $7.80\left(\mathrm{td}, 4 \mathrm{H}, \mathrm{H}_{4}, J=7.6 \mathrm{~Hz}, J=1.6 \mathrm{~Hz}\right) ; 7.30-7.26\left(\mathrm{~m}, 4 \mathrm{H}, \mathrm{H}_{5}\right) ; 4.84\left(\mathrm{~s}, 2 \mathrm{H}, \mathrm{S}_{-} \mathrm{CH}_{2}-\mathrm{S}\right)$

${ }^{13} \mathrm{C} \mathrm{NMR}\left(100 \mathrm{MHz} \mathrm{CDCl}_{3}\right): \delta$ in ppm 155.6, 155.3, 149, 148.8, 136.7, 123.8, 121.3, 118.7, 33.6 ES-MS (+) $m / z: 543[\mathrm{M}+\mathrm{H}]^{+}$.

\section{(1) $\left[\mathrm{Ru}(\right.$ tpyada $)($ tpySH) $]\left(\mathrm{PF}_{6}\right)_{2}$}

A solution of $\mathrm{Ru}(\mathrm{tpyada}) \mathrm{Cl}_{3}(0.081 \mathrm{~g} ; 0.141 \mathrm{mmol})$ and tpySH $(0.041 \mathrm{~g} ; 0.142 \mathrm{mmol})$ in $20 \mathrm{~mL}$ of methanol was refluxed in the dark for 24 hours. After cooling down to room temperature a

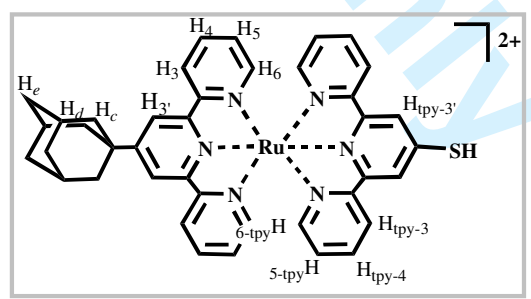


solution of $\mathrm{NH}_{4} \mathrm{PF}_{6}$ in methanol was added to the reaction and a dark solid precipitated out. The solid was collected by filtration and washed with methanol and diethyl ether giving $0.093 \mathrm{~g}$ of the product (67 \%). ${ }^{1} \mathrm{H}-\mathrm{NMR}\left(300 \mathrm{MHz}, \mathrm{CD}_{3} \mathrm{CN}\right): \delta$ in ppm 9.05 (s, 2H, $\mathrm{H}_{3^{\prime} / \text { tpy-3') }}$ ); 8.93 (s, 2H, H $3^{\prime} /$ tpy-3'); 8.68 (d, $\left.2 \mathrm{H}, \mathrm{H}_{3 / \text { tpy-3}}, J=8.7 \mathrm{~Hz}\right) ; 8.58\left(\mathrm{~d}, 2 \mathrm{H}, \mathrm{H}_{3 / \text { tpy-3}}, J=8.4 \mathrm{~Hz}\right) ; 8.01-7.81\left(\mathrm{~m}, 4 \mathrm{H}, \mathrm{H}_{4}, \mathrm{H}_{\text {tpy-4}}\right) ; 7.35(\mathrm{~d}, 2 \mathrm{H}$, $\mathrm{H}_{6 / \text { tpy- } 6}, J=5.4 \mathrm{~Hz}$ ); 7.29 (d, 2H, $\left.\mathrm{H}_{6 / \text { tpy-6}}, J=4.2 \mathrm{~Hz}\right) ; 7.21-7.14$ (m, 4H, H5, H $\mathrm{H}_{c}, \mathrm{H}_{d}$ ); 1.97 (br s, 6H, $\mathrm{H}_{e}$ ). ES-MS (+) $m / z: 733\left[\mathrm{M}-2 \mathrm{PF}_{6}\right]^{+\cdot} \mathrm{UV}-\mathrm{Vis}$ in $\mathrm{CH}_{3} \mathrm{CN}: \lambda_{\max }$ in nm $\left(\varepsilon\right.$ in $\mathrm{M}^{-}$ $\left.{ }^{1} \mathrm{~cm}^{-1}\right) 237 ; 276 ; 308 ; 492$.

\section{(2) $\left[\mathrm{Ru}(\right.$ biptpy)(tpySH) $]\left(\mathrm{PF}_{6}\right)_{2}$}

The complex was synthesised using the method described previously for $[\mathrm{Ru}($ tpyada $)(\mathrm{tpySH})]\left(\mathrm{PF}_{6}\right)_{2}$ starting with $[\mathrm{Ru}($ biptpy $)] \mathrm{Cl}_{3}(0.150 \mathrm{~g} ; 0.254 \mathrm{mmol})$ and tpySH (0.199 g; $0.70 \mathrm{mmol}$ ). A methanolic solution of $\mathrm{NH}_{4} \mathrm{PF}_{6}$ was added to the reaction and a solid precipitated. The solid was collected by filtration and was purified by silica chromatography

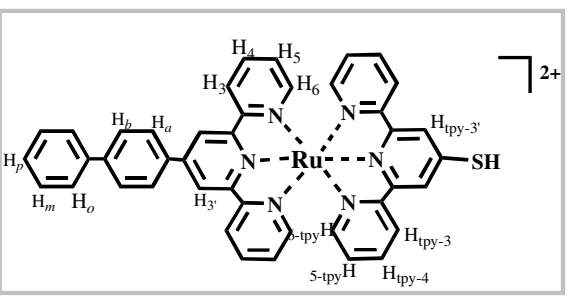
(eluents: $\mathrm{CH}_{3} \mathrm{CN}$ followed by $\mathrm{CH}_{3} \mathrm{CN} / \mathrm{H}_{2} \mathrm{O} / \mathrm{KNO}_{3}$ (sat) (70: 0.5:1.5)). The counterion of the product was changed with a methanolic solution of $\mathrm{NH}_{4} \mathrm{PF}_{6}$ obtaining $0.010 \mathrm{~g}(43 \%)$ of the desired compound as a red solid.

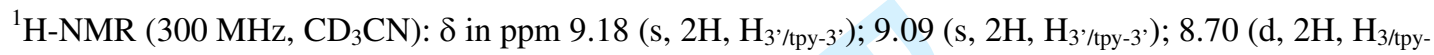
$\left.{ }_{3}, J=8.1 \mathrm{~Hz}\right) ; 8.67\left(\mathrm{~d}, 2 \mathrm{H}, \mathrm{H}_{3 / \mathrm{tpy}-3}, J=8.4 \mathrm{~Hz}\right) ; 8.34\left(\mathrm{~d}, 2 \mathrm{H}, \mathrm{H}_{a / b}, J=8.4 \mathrm{~Hz}\right) ; 8.06\left(\mathrm{~d}, 2 \mathrm{H}, \mathrm{H}_{a / b}, J=\right.$ $8.1 \mathrm{~Hz}) ; 7.98-7.93\left(\mathrm{~m}, 4 \mathrm{H}, \mathrm{H}_{4}, \mathrm{H}_{\mathrm{tpy}-4}\right) ; 7.86\left(\mathrm{~d}, 2 \mathrm{H}, \mathrm{H}_{o}, J=7.2 \mathrm{~Hz}\right) ; 7.58\left(\mathrm{~m}, 3 \mathrm{H}, \mathrm{H}_{m}, \mathrm{H}_{p}\right) ; 7.49$ (d, $4 \mathrm{H}$, $\left.\mathrm{H}_{6}, \mathrm{H}_{\text {tpy-6}}, J=6.9 \mathrm{~Hz}\right) ; 7.29-7.19\left(\mathrm{~m}, 4 \mathrm{H}, \mathrm{H}_{5}, \mathrm{H}_{\text {tpy-5}}\right)$. ES-MS (+) m/z: $719\left[\mathrm{M}-2 \mathrm{PF}_{6}\right]^{+} ; 359.5[\mathrm{M}-$ $\left.2 \mathrm{PF}_{6}\right]^{+2}$.

\section{(3) $\left[\mathrm{Ru}(\mathrm{pm}-\boldsymbol{\beta}-\mathrm{CD}(\mathrm{ttp}))\left(\mathrm{tpySH}^{\mathrm{s}}\right)\right]\left(\mathrm{PF}_{6}\right)_{2}$}

$[\mathrm{Ru}(\mathrm{pm}-\beta-\mathrm{CD}(\mathrm{ttp}))] \mathrm{Cl}_{3} \quad(0.046 \mathrm{~g} ; 0.024 \mathrm{mmol})$ was dissolved in $5 \mathrm{~mL}$ of methanol with tpySH $(0.017 \mathrm{~g} ; 0.059 \mathrm{mmol})$ in the presence of a few drops of N-ethylmorpholine and refluxed for 24 hours. The reaction was allowed to cool down to room temperature and then filtered through celite.

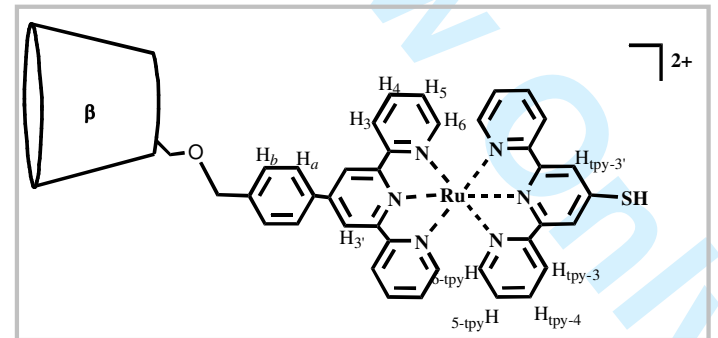
A methanolic solution of $\mathrm{NH}_{4} \mathrm{PF}_{6}$ was added to the filtrate and the solvent was evaporated. The residue 
was extracted with $\mathrm{CH}_{2} \mathrm{Cl}_{2}$ and the insoluble solid was filtered out and the filtrate was evaporated yielding a red solid. The red residue was purified by size exclusion chromatography (BioBeads SX3) using DMF/THF (0.5:1). This solid was then stirred in a 1:1 mixture of methanol and pyridine with 0.3 $\mathrm{mL}$ of hydrazine monohydrate giving $0.047 \mathrm{~g}(80 \%)$ of the product as a red solid.

${ }^{1} \mathrm{H}-\mathrm{NMR}\left(300 \mathrm{MHz}, \mathrm{CD}_{3} \mathrm{CN}\right.$ ): $\delta$ in ppm 8.99 (s, 2H, $\mathrm{H}_{3^{\prime} / \text { tpy-3 }}$ ); 8.74 (s, 2H, $\mathrm{H}_{3^{\prime} / \text { tpy-3’' }}$ ); 8.71 (d, 2H, $\mathrm{H}_{3 / \text { tpy- }}$ ${ }_{3}, J=8.2 \mathrm{~Hz}$ ); 8.65 (d, 2H, $\left.\mathrm{H}_{3 / \mathrm{py}-3}, J=7.5 \mathrm{~Hz}\right) ; 8.19$ (d, 2H, $\left.\mathrm{H}_{a / b}, J=8.0 \mathrm{~Hz}\right) ; 7.97-7.89$ (m, 4H, $\mathrm{H}_{4}$,

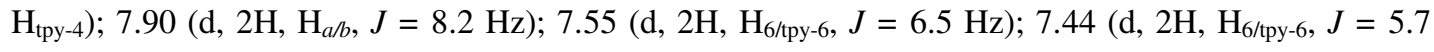

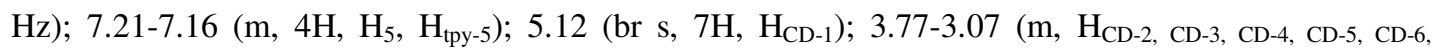
$\left.\mathrm{CD}_{\mathrm{CH} 3}\right)$ ES-MS (+) $m / z: 2102\left[\mathrm{M}-2 \mathrm{PF}_{6}\right]^{+}$.

\section{(4) $\left[(t\right.$ tp $) \operatorname{Ru}\left(\right.$ tpySCH$\left.\left._{2} \operatorname{Stpy}\right) \operatorname{Ru}(\operatorname{ttp})\right]\left(\mathrm{PF}_{6}\right)_{4}$}

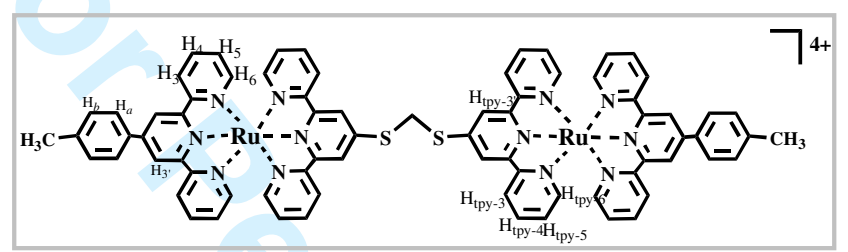

A suspension of tpySCH $\mathrm{SH}_{2} \mathrm{Stpy}(0.029 \mathrm{~g} ; 0.069 \mathrm{mmol})$ and $\mathrm{Ru}(\mathrm{ttp}) \mathrm{Cl}_{3}(0.069 ; 0.13 \mathrm{mmol})$ in $10 \mathrm{~mL}$ of methanol was prepared. A few drops of $\mathrm{N}$-ethylmorpholine were added and the reaction was refluxed for 30 minutes. After cooling down to room temperature the solution was filtered through celite. A methanolic solution of $\mathrm{NH}_{4} \mathrm{PF}_{6}$ was added to the filtrate leading to precipitation of a dark red solid. The solid was collected by filtration and washed with methanol. The precipitate was purified by column chromatography on silica (eluent: $\mathrm{CH}_{3} \mathrm{CN} / \mathrm{H}_{2} \mathrm{O} / \mathrm{KNO}_{3}$ (sat) (70:5:15)). The excess of $\mathrm{KNO}_{3}$ was eliminated by adding $\mathrm{NH}_{4} \mathrm{PF}_{6}$ to a methanol solution of the fraction collected from the column yielding $0.08 \mathrm{~g}$ of the desired compound. Yield: $79 \%$.

${ }^{1} \mathrm{H}-\mathrm{NMR}\left(400 \mathrm{MHz}, \mathrm{CD}_{3} \mathrm{CN}\right.$ ): $\delta$ in ppm 8.99 (s, 4H, $\mathrm{H}_{3^{\prime} / \text { tpy-3 }}$ ); 8.90 (s, 4H, $\mathrm{H}_{3^{\prime} / \text { tpy-3}}$ ); 8.67 (d, 4H, $\mathrm{H}_{3 / \mathrm{tpy}-}$ $\left.{ }_{3}, J=8.4 \mathrm{~Hz}\right) ; 8.65\left(\mathrm{~d}, 4 \mathrm{H}, \mathrm{H}_{3 / \mathrm{py}-3}, J=8.0 \mathrm{~Hz}\right) ; 8.11\left(\mathrm{~d}, 4 \mathrm{H}, \mathrm{H}_{a / b}, J=8.4 \mathrm{~Hz}\right) ; 7.97-7.89\left(\mathrm{~m}, 8 \mathrm{H}, \mathrm{H}_{4}\right.$,

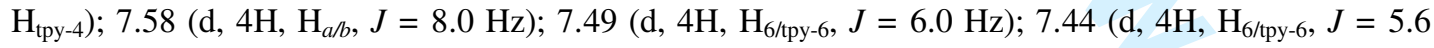
$\mathrm{Hz}) ; 7.23-7.16$ (m, 8H, $\mathrm{H}_{5}, \mathrm{H}_{\text {tpy-5}}$ ); 5.65 (s, 2H, S- $\left.\mathrm{CH}_{2}-\mathrm{S}\right) ; 2.53$ (s, 6H, $\mathrm{CH}_{3}$ ).

${ }^{13} \mathrm{C}$ NMR (100 MHz, $\mathrm{CD}_{3} \mathrm{CN}$ ): $\delta$ in ppm 159.3, 158.8, 156.5, 156, 153.6, 153.5, 149.4, 148.3, 142, 139 , $134.9,131.3,128.6,128.5,125.8,125.5,122.6,122.4,35.1,21.3$. ES-MS (+) $m / z: 841\left[\mathrm{M}-2 \mathrm{PF}_{6}\right]^{+2}$; $512\left[\mathrm{M}-3 \mathrm{PF}_{6}\right]^{+3}$. UV-Vis in $\mathrm{CH}_{3} \mathrm{CN}: \lambda_{\max }$ in $\mathrm{nm}\left(\varepsilon\right.$ in $\left.\mathrm{M}^{-1} \mathrm{~cm}^{-1}\right) 287$ (144120); 307 (154560); 494 (64980). 


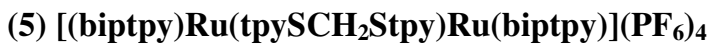

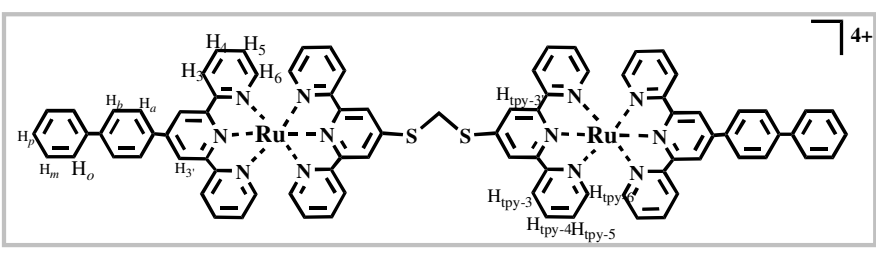

The complex [(biptpy)Ru(tpySCH $\left.\mathrm{St}_{2} \mathrm{Stpy}\right) \mathrm{Ru}\left(\right.$ biptpy)] $\left(\mathrm{PF}_{6}\right)_{4}$ was synthesised using the same method described previously for $\left[\left(\operatorname{ttpRu}\left(\mathrm{tpySCH} \mathrm{S}_{2} \mathrm{Stpy}\right) \mathrm{Ru}(\mathrm{ttp})\right]\left(\mathrm{PF}_{6}\right)_{4}\right.$ starting with $0.049 \mathrm{~g}(0.084 \mathrm{mmol})$ of $[\mathrm{Ru}$ (biptpy) $] \mathrm{Cl}_{3}$ and $0.022 \mathrm{~g}(0.053 \mathrm{mmol})$ of tpySCH $\mathrm{St}_{2}$ in $5 \mathrm{~mL}$ of methanol with a few drops of N-ethylmorpholine. The product was obtained as $0.082 \mathrm{~g}$ of a dark red solid with a yield of $93 \%$.

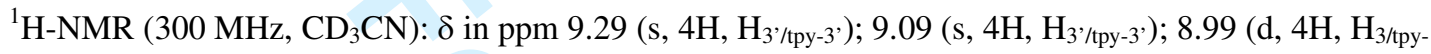
$\left.{ }_{3}, J=8 \mathrm{~Hz}\right) ; 8.69$ (d, 4H, $\left.\mathrm{H}_{3 / \text { tpy- } 3}, J=8 \mathrm{~Hz}\right) ; 8.33$ (d, 4H, $\left.\mathrm{H}_{a / b}, J=8.5 \mathrm{~Hz}\right) ; 8.06\left(\mathrm{~d}, 4 \mathrm{H}, \mathrm{H}_{a / b}, J=8.5\right.$

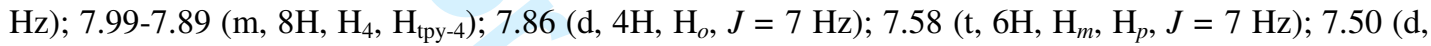
$\left.4 \mathrm{H}, \mathrm{H}_{6 / \text { tpy- } 6}, J=7 \mathrm{~Hz}\right) ; 7.45$ (d, 4H, $\left.\mathrm{H}_{6 / \text { tpy- } 6}, J=4.5 \mathrm{~Hz}\right) ; 7.24-7.16\left(\mathrm{~m}, 8 \mathrm{H}, \mathrm{H}_{5}, \mathrm{H}_{\text {tpy-5}}\right) ; 6.06$ (s, 2H, S$\left.\mathrm{CH}_{2}-\mathrm{S}\right) .{ }^{13} \mathrm{C}$ NMR $\left(75 \mathrm{MHz}, \mathrm{CD}_{3} \mathrm{CN}\right): \delta$ in ppm 159, 153.5, 153.3, 148.6, 144, 138.9, 136.6, 130.1, 129.2, 128.9, 128.4, 128, 126, 125.4, 123, 122.4, 31.5. ES-MS (+) m/z: $903\left[\mathrm{M}-2 \mathrm{PF}_{6}\right]^{+2} ; 553[\mathrm{M}-$ $\left.3 \mathrm{PF}_{6}\right]^{+3}$. Anal. Found: C, 48.81; H, 3.07; N, 7.76. Calcd for $\left(\mathrm{C}_{85} \mathrm{H}_{60} \mathrm{~N}_{12} \mathrm{Ru}_{2} \mathrm{~S}_{2}\left(\mathrm{PF}_{6}\right)_{4}\right)$ : C, 48.72; H, 2.89; $\mathrm{N}$, 8.02. UV-Vis in $\mathrm{CH}_{3} \mathrm{CN}: \lambda_{\max }$ in $\mathrm{nm}\left(\varepsilon\right.$ in $\left.\mathrm{M}^{-1} \mathrm{~cm}^{-1}\right)$ 230(sh) (123450); 287 (158340); 309 (196870); 327(sh) (157390); 495 (81350).

\section{$\left[(\mathrm{pm}-\beta-\mathrm{CD}(\mathrm{ttp})) \operatorname{Ru}\left(\mathrm{tpySCH}_{2} \mathrm{Stpy}\right) \operatorname{Ru}(\mathrm{pm}-\beta-\mathrm{CD}(\mathrm{ttp}))\right]\left(\mathrm{PF}_{6}\right)_{4}$}

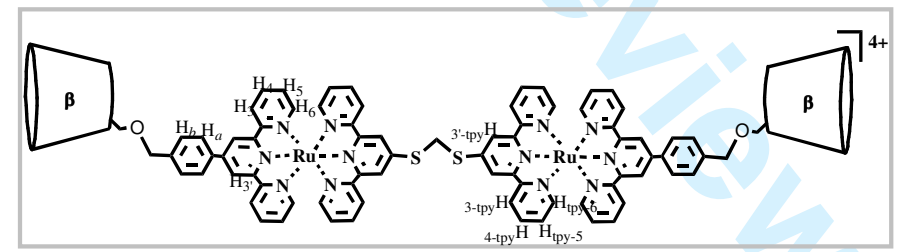

A solution of $[\mathrm{Ru}(\mathrm{pm}-\beta-\mathrm{CD}(\mathrm{ttp}))] \mathrm{Cl}_{3}(0.101 \mathrm{~g} ; 0.052 \mathrm{mmol})$ was refluxed with tpySCH $\mathrm{Stpy}_{2}(0.014 \mathrm{~g}$; $0.033 \mathrm{mmol}$ ) in $10 \mathrm{~mL}$ of methanol with a few drops of $\mathrm{N}$-ethylmorpholine for 24 hours. After cooling down to room temperature the reaction was filtered through celite and a methanolic solution of $\mathrm{NH}_{4} \mathrm{PF}_{6}$ was added to the filtrate. The solvent was evaporated and the residue was extracted with $\mathrm{CH}_{2} \mathrm{Cl}_{2}$. The mixture was filtered and the filtrate was evaporated yielding a red solid. The red residue was purified by size exclusion chromatography BioBeads SX3 using DMF/THF (1:1) yielding $0.064 \mathrm{~g}(55 \%)$ of the product. 
${ }^{1} \mathrm{H}-\mathrm{NMR}\left(300 \mathrm{MHz}, \mathrm{CD}_{3} \mathrm{CN}\right.$ ): $\delta$ in ppm 9.00 (s, 4H, $\mathrm{H}_{3^{\prime} / \text { tpy-3 }}$ ); 8.92 (s, 4H, $\mathrm{H}_{3^{\prime} / \text { tpy-3 }}{ }^{\prime}$ ); 8.66 (d, 8H, $\mathrm{H}_{3}$, $\left.\mathrm{H}_{\text {tpy-3}}, J=8.1 \mathrm{~Hz}\right) ; 8.20\left(\mathrm{~d}, 4 \mathrm{H}, \mathrm{H}_{a / b}, J=8.1 \mathrm{~Hz}\right) ; 7.97-7.93\left(\mathrm{~m}, 8 \mathrm{H}, \mathrm{H}_{4}, \mathrm{H}_{\text {tpy-4}}\right) ; 7.74\left(\mathrm{~d}, 4 \mathrm{H}, \mathrm{H}_{a / b}, J=\right.$ 7.8 Hz); 7.50-7.43 (m, 8H, $\mathrm{H}_{6}, \mathrm{H}_{\text {tpy-6) }}$ ); 7.25-7.17 (m, 8H, $\left.\mathrm{H}_{5}, \mathrm{H}_{\text {tpy-5}}\right)$; 5.28-5.12 (m, 14H, $\left.\mathrm{H}_{\mathrm{CD}-1}\right) ; 4.73$ (s,

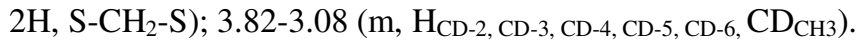

${ }^{13} \mathrm{C}$ NMR $\left(100 \mathrm{MHz}, \mathrm{CD}_{3} \mathrm{CN}\right): \delta$ in ppm 159.2, 158.7, 156.6, 155.9, 153.5, 149, 142.5, 139, 136.9, $129.7,128.8,128.5,125.8,125.5,122.5,98.9,83.2,82.7,80.1,79.9,73.3,72.5,71.9,70.6,61.5,59.2$, 58.8, 35.1, 32.1, 30.3. ES-MS (+) $\mathrm{m} / z: 1454\left[\mathrm{M}-3 \mathrm{PF}_{6}\right]^{+3}$.

\section{References}

1. Obeng, Y. S.; Bard, A. J., Langmuir 1991, 7, 195.

2. Kim, Y.-T.; MacCarley, R. L.; Bard, A. J., J. Phys. Chem. 1992, $96,7416$.

3. Otsuki, J.; Kameda, H.; Tomihira, S.; Sakaguchi, H.; Takido, T., Chem. Lett. 2002, $\overline{6}, 610$.

4. Forster, R. J.; O Kelly, J. P., J. Electrochem. Soc. 2001, 148, E31.

5. Bertoncello, P.; Kefalas, E.; Pikramenou, Z.; Unwin, P. R.; Forster, R. J., J. Phys. Chem. B $\mathbf{2 0 0} \overline{\mathbf{6}}$, $110,10063$.

6. Will, G.; Nagaraja Rao, J. S. S.; Fitzmaurice, D., J. Mater. Chem. 1999, 9, 2297.

7. Auditore, A.; Tuccitto, N.; Marzanni, G.; Quici, S.; Puntoriero, F.; Campagna, S.; Licciardello, A., Chem. Comm. 2003, 19, 2494.

8. Maskus, M.; Abruna, H. D., Langmuir 1996, $12,445 \overline{5}$.

9. Park, J.; Pasupathy, A. N.; Goldsmith, J. I.; Chang, C.; Yaish, Y.; Petta, J. R.; Rinkoski, M.; Sethna, | J. P.; Abruna, H. D.; McEuen, P. L., Nature 2002, 722.

10. Park, J.; Pasupathy, A. N.; Goldsmith, J. I.; Soldatov, A. V.; Chang, C.; Yaish, Y.; Sethna, J. P.; Abruna, H. D.; Ralph, D. C.; McEuen, P. L., Thin Solid Films 2003, 438, 457.

11. Figgemeier, E.; Constable, E. C.; Housecroft, C. E.; Zimmermann, Y. C., Langmuir 2004, $20,9242$. 12. Haider, J. M.; Williams, R. M.; De Cola, L.; Pikramenou, Z., Angew. Chem. Int. Ed. 2003, $\overline{4} 2$, 1830 .

13.Haider, J. M.; Pikramenou, Z., Eur. J. Inorg. Chem. 2001, 189.

| 14. Pereira Silva, M. J. J.; Haider, J. M.; Heck, R.; Chavarot, M.; Marsura, A.; Pikramenou, Z., Supramol. Chem. 2003, 15, 563.

15. Yang, Y.-W.; Chen, Y.; Liu, Y., Inorg. Chem. 2006, 45, 3014.

16. Haider, J. M.; Pikramenou, Z., Chem. Soc. Rev. 2005, $34,120$.

17. Nelissen, H. F. M.; Kercher, M.; De Cola, L.; Feiters, M. C.; Nolte, R. J. M., Chem. Eur. J. 2002, $\overline{8}$, 5407.

| 18. Mortellaro, M. A.; Nocera, D. G. N., J. Am. Chem. Soc. 1996, $118,7414$.

19. Li, C.; Fan, W.; Straus, D. A.; Leu, B.; Asano, S.; Zhang, D.; Han, J.; Meyyappan, M.; Żhou, C., J. Am. Chem. Soc. 2004, 126, 7750.

20. Faiz, J.; Williams, R. M.; Pereira Silva, M. J. J.; Cola, L. D.; Pikramenou, Z., J. Ám. Chem. Soc. 2006, 128,4520 .

21. Faiz, J.; Spencer, N.; Pikramenou, Z., Org. Biomol. Chem. 2005, $3,4239$.

22. Testaferri, L.; Tiecco, M.; Tingoli, M.; Chianelli, D.; Montanucci, M., Synthesis 1983, 9, 751.

23. Katz, L.; Schroeder, W., J. Org. Chem. 1953, $18,103$.

24. Tam, J. P.; Wu, C. R.; Liu, W.; Zhang, J. W., J. Am. Chem. Soc. 1991, $113,6657$.

25. Wallace, T. J., J. Am. Chem. Soc 1964, 86, 2018.

26. Jeitler, J. R.; Turnbull, M. M.; Wikaira, J. L., Inorg. Chim. Acta 2003, $351,331$.

\begin{tabular}{|c|}
\hline Formatted: Font: Italic \\
\hline Formatted: Font: Italic \\
\hline Formatted: Font: Italic \\
\hline Formatted: Font: Italic \\
\hline Formatted: Font: Italic \\
\hline Formatted: Font: Italic \\
\hline Formatted: Font: Italic \\
\hline Formatted: Font: Italic \\
\hline Deleted: 6890 , \\
\hline Formatted: Font: Italic \\
\hline Formatted: Font: Italic \\
\hline Formatted: Font: Italic \\
\hline Formatted: Font: Italic \\
\hline Deleted: M. J. J. \\
\hline Deleted: J. M. \\
\hline Deleted: R. \\
\hline Deleted: M. \\
\hline Deleted: Ying-Wei \\
\hline Deleted: Yong \\
\hline Formatted: Font: Italic \\
\hline Formatted: Font: Italic \\
\hline Formatted: Font: Italic \\
\hline Formatted: Font: Italic \\
\hline Formatted: Font: Italic \\
\hline Deleted: $\mathrm{P}$. \\
\hline Formatted: Font: Italic \\
\hline Formatted: Font: Italic \\
\hline Formatted: Font: Italic \\
\hline Formatted: Font: Italic \\
\hline Formatted: Font: Italic \\
\hline $\begin{array}{l}\text { Deleted: Reactions of thiols with } \\
\text { sulfoxides. }\end{array}$ \\
\hline Formatted: Font: Italic \\
\hline Formatted: Font: Italic \\
\hline
\end{tabular}


27. Murguly, E.; Norsten, T. B.; Branda, N., J. Chem. Soc., Perkin Trans. 2 1999, 2789.

| 28. Anjali, K. S.; Vittal, J. J.; Dean, P. A. D., Inorg. Chim. Acta 2003, 351, 79.

29. Gordon, A. J.; Ford, R. A., The Chemist's Companion. John Wiley \& Sons: New York, 1972.

30. Sauvage, J. P.; Collin, J. P.; Chambron, J. C.; Guillerez, S.; Coudret, C.; Balzani, V.; Barigelletti,

| F.; De Cola, L.; Flamigni, L., Chem. Rev. 1994, 94, 993.

31. Maestri, M.; Armaroli, N.; Balzani, V.; Constable, E. C.; Cargill Thompson, A. M. W., Inorg.

Chem. 1995, 34, 2759.

32. Alcock, N. W.; Barker, P. R.; Haider, J. M.; Hannon, M. J.; Painting, C. L.; Pikramenou, Z.;

Plummer, E. A., J. Chem. Soc., Dalton Trans. 2000, 9, 1447.

33. Khramov, A.N.; Collinson, M.M. Anal. Chem. 2000, 72, 2943.

34. Bard, A.J.; Faulkner, L.R. Electrochemical Methods: Fundamentals and Applications, Wiley, New York, $2^{\text {nd }}$ Edition, 2001

35. Sheldrick, G. M., In University of Gottingen, Germany.: Program package for crystal structure determination.

36. Demas, J. N.; Crosby, G. A., J. Phys. Chem. 1971, 75, 991.

37. Nakamura, K., Bull. Chem. Soc. Jpn. 1982, 55, 2697.
Formatted: Font: Italic

Formatted: Font: Italic

Formatted: Font: Italic

Formatted: Font: Italic

Deleted: II

Formatted: Font: Italic

Deleted: 4

Deleted: 5

Formatted: Font: Italic

Deleted: 6

Formatted: Font: Italic 